\title{
3-Arylaziridine-2-carboxylic Acid Derivatives and (3-Arylaziridin-2-yl)ketones: The Aziridination Approaches
}

\author{
Boriss Strumfs ${ }^{1,2}$, Romans Uljanovs ${ }^{2}$, Kirils Velikijs ${ }^{2}$, Peteris Trapencieris ${ }^{1}$ and Ilze Strumfa ${ }^{2, *(D)}$ \\ 1 Latvian Institute of Organic Synthesis, 21 Aizkraukles Street, LV-1006 Riga, Latvia; boriss@osi.lv (B.S.); \\ peteris@osi.lv (P.T.) \\ 2 Department of Pathology, Riga Stradins University, 16 Dzirciema Street, LV-1007 Riga, Latvia; \\ Romans.Uljanovs@rsu.lv (R.U.); Kirils.Velikijs@rsu.lv (K.V.) \\ * Correspondence: Ilze.Strumfa@rsu.lv
}

check for

updates

Citation: Strumfs, B.; Uljanovs, R.; Velikijs, K.; Trapencieris, P.; Strumfa, I. 3-Arylaziridine-2-carboxylic Acid Derivatives and (3-Arylaziridin-2-yl) ketones: The Aziridination Approaches. Int. J. Mol. Sci. 2021, 22, 9861. https://doi.org/10.3390/ ijms22189861

Academic Editor: Andrea Pace

Received: 11 August 2021

Accepted: 9 September 2021

Published: 13 September 2021

Publisher's Note: MDPI stays neutral with regard to jurisdictional claims in published maps and institutional affiliations.

Copyright: (c) 2021 by the authors. Licensee MDPI, Basel, Switzerland. This article is an open access article distributed under the terms and conditions of the Creative Commons Attribution (CC BY) license (https:// creativecommons.org/licenses/by/ $4.0 /$ )

\begin{abstract}
Aziridination reactions represent a powerful tool in aziridine synthesis. Significant progress has been achieved in this field in the last decades, whereas highly functionalized aziridines including 3-arylated aziridine-2-carbonyl compounds play an important role in both medical and synthetic chemistry. For the reasons listed, in the current review we have focused on the ways to obtain 3-arylated aziridines and on the recent advances (mainly since the year 2000) in the methodology of the synthesis of these compounds via aziridination.
\end{abstract}

Keywords: aziridines; aziridination; imines; carbenes; nitrenes

\section{Introduction}

The finding of new potential anti-cancer and antiviral drugs, as well as the development of efficient methods for synthesizing them and their appropriate building blocks, is one of the most important problems in medical chemistry. Due to the electrophilic nature of the aziridine ring, derivatives of aziridine-2-carboxylic acid react with various nucleophiles, therefore becoming interesting synthetic substrates in order to create different amino acids, alkanolamines, and heterocyclic compounds [1]. Some derivatives of aziridine-2-carboxylic acid, namely, imexon, azimexon [2], and leakadine [3] were developed as anti-tumour agents and have shown anti-cancer immunomodulatory activity.

It is also known that derivatives of aromatic $\alpha, \beta$-unsaturated carboxylic acids, such as caffeic acid [4] and its esters [5] have demonstrated cytotoxic effects and promotion of apoptosis in lung carcinoma cells. Its analogue, $p$-coumaric acid, has shown an anti-angiogenic effect [6], which is important to stop tumor development. In this light, 3-arylated derivatives of aziridine-2-carboxylic acid 1a,b (Scheme 1) and similar compounds containing an aziridine ring in phenylpropionic acid side chain could be predicted to have anti-cancer properties.

Authors of previous reviews have summarized the recent advances in the synthesis of aziridine-2-carbonyl compounds (Zalubovskis and Ivanova [7]) and in the overall aziridine chemistry and synthesis (Singh [8] and Luisi [9]). The generally known methods to obtain these compounds include aziridination, Gabriel-Cromwell cyclization of aminoalcohols, Diels-Alder cycloaddition to azirines, Baldwin rearrangement, and others. This review is focused on synthesizing 3-aryl substituted aziridines 1a-c (Scheme 1) via aziridination since aziridination has a wide perspective, especially in stereoselective synthesis; it is tolerant towards various functional groups and can be realized in mild conditions which are important for construction of more complex molecules. The structures 1a-c (Scheme 1) have two asymmetric carbons in $2(\alpha-)$ and $3(\beta-)$ positions of aziridine ring, and therefore stereoselectivity of synthetic methods is important. Aziridination has two variations: carbon addition to the imine double bond via carbene sources (Scheme 1A) and nitrogen addition to the olefin double bond via nitrene sources (Scheme 1B). 


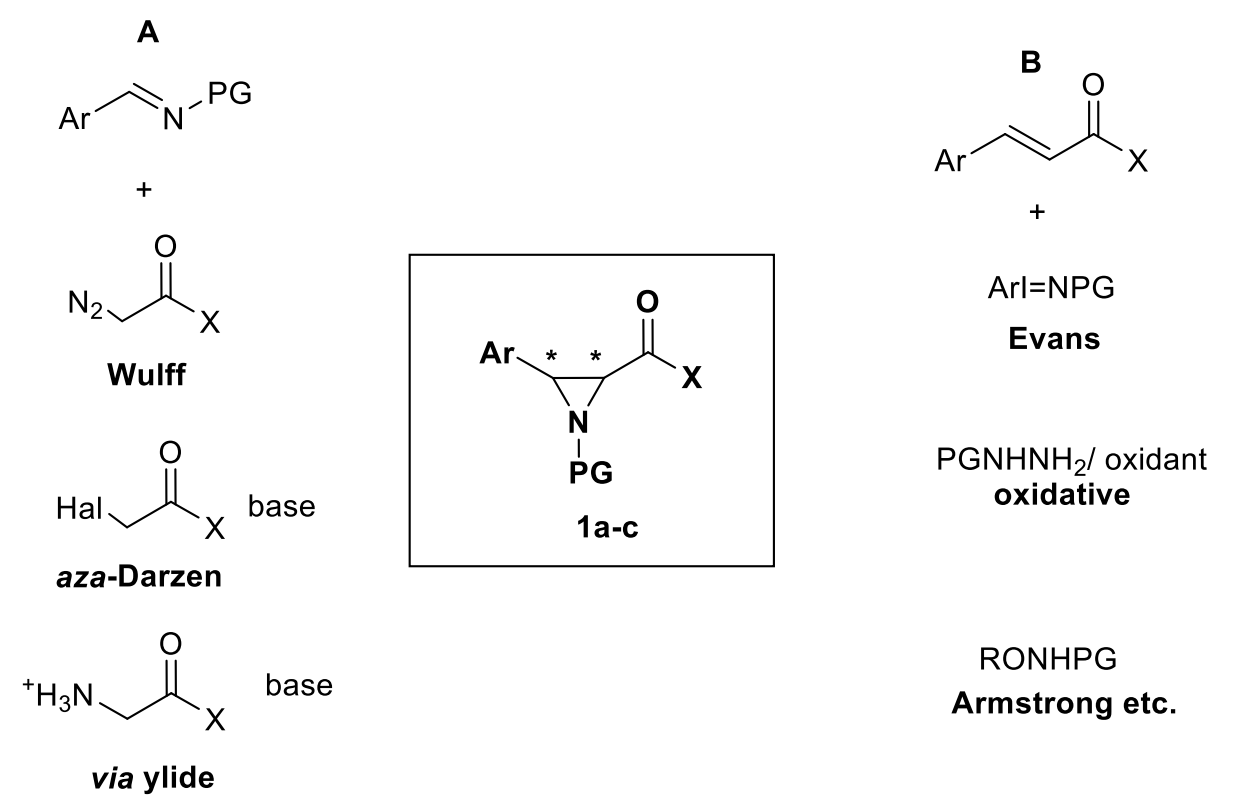

Scheme 1. The general pathways of aziridination. (A) carbon insertion in the imine double bond via carbene sources; (B) ni-trogen insertion in the olefin double bond via nitrene sources.

\section{Aziridination of Imines (Path A)}

This aziridination approach includes:

- Aziridination of imines with a diazo carbene source (AZ reaction);

- Variations of aza-Darzen reaction;

- Aziridination with ylides.

\subsection{Aziridination of Imines with a Diazo Carbene Source (Wulff's AZ Reaction)}

Catalytic asymmetric aziridination (AZ reaction) of imines using a carbene source represents the best explored and most popular group of synthetic methods of 3-arylated aziridines 1a-c (Scheme 1). The most common carbene sources are diazo compounds, e.g., ethyl diazoacetate (EDA) and its analogues.

Fundamental series of research in catalytic $\mathrm{C}=\mathrm{N}$ bound (imine) aziridination with diazo carbene sources (Scheme 2) was made by Wulff's and Thurston's teams [10-32]. A particularly large number of scientific publications have been prepared by the Wulff's group [10-29,31,32]. At first, it was established that the best catalysts for aryl imine 2a (Scheme 2) and ethyl diazoacetate (EDA) 3a (Scheme 2) reactions were complexes of $(S)$ VAPOL 4a (Scheme 3) and (S)-VANOL 5a ligands (Scheme 3) with $\mathrm{B}\left(\mathrm{OPh}_{3}\right)$. cis-Aziridine esters 1a1 (Scheme 2) were obtained in good (69-91\%) yields and high enantiomeric (ee) purity [10-12]. AZ reaction-based synthesis of L-DOPA [10] and (-)-chloroamphenicol [11] and florfenicol [12] have been demonstrated. In the case of dianisylmethyl (DAM) substituent 3-aryl-NH, aziridines were successfully obtained after hydrogenation in 83-100\% yields [13]. Instead of ester diazo carbene source $\mathbf{3 a}$, diazoamide $\mathbf{3 b}$ (Scheme 2) produced trans-aziridines $\mathbf{1 b} \mathbf{1}$ as illustrated in the Scheme 2 [18]. 


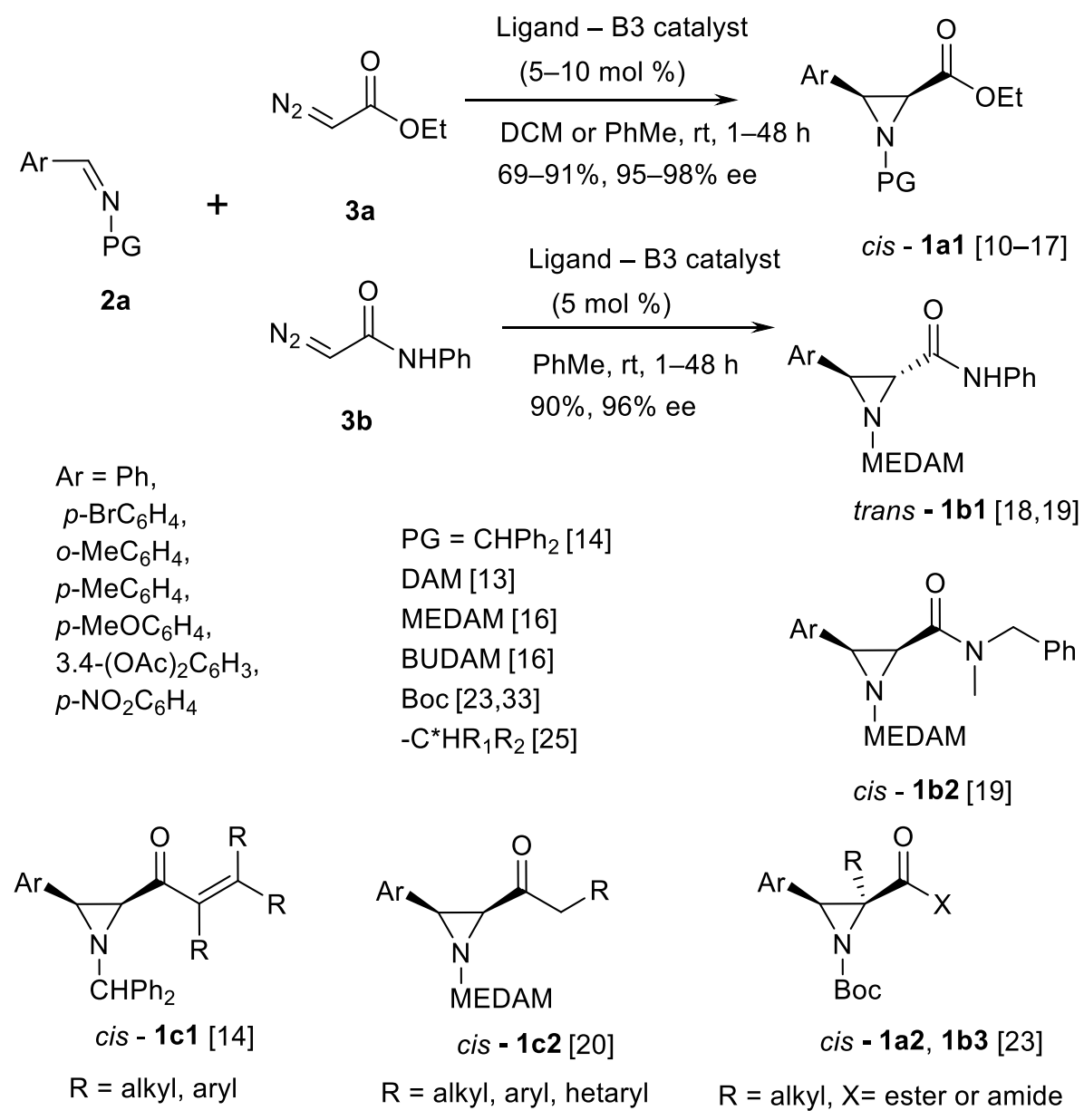

Scheme 2. Wulff's type aziridination (AZ reaction) [10-29,31,32].<smiles>Oc1c(-c2c(-c3ccccc3)cc3ccc4ccccc4c3c2O)c(-c2ccccc2)cc2ccc3ccccc3c12</smiles>

(S)-VAPOL $\mathbf{4 a}$<smiles>Oc1c(-c2ccccc2)cc2ccccc2c1-c1c(-c2ccccc2)cc2ccccc2c1O</smiles>

(S)-VANOL 5a iso -VAPOL ligand [28]

Modified ligand [27]<smiles>[R]c1ccc2cc(-c3ccccc3)c(-c3cc4ccc([R])cc4c(-c4ccccc4)c3O)c(O)c2c1</smiles>

5b R=Hal, Me, $t$-Bu

Scheme 3. Aryl ligands for Wulff's aziridination [10-14,27,28].

Aziridinyl vinyl ketones 1c1 (Scheme 2) also have been obtained from the corresponding diazo ketones using AZ reaction in presence of (S)-VANOL and (S)-VAPOL-derived boron complex catalysts in 19 examples at 35-90\% yields [14]. Series of 3-arylated aziridinyl ketones 1c2 (Scheme 2; seven examples, 62-90\% yields, 85-99\% ee) have been synthesized in tandem acylation-aziridination of trimethylsilyldiazomethane [20] using (S)-VAPOL and $(R)$-VANOL ligands. N-Boc-imines $\mathbf{2 a}$ (Scheme 2) are more reactive toward diazo compounds and allow to reach trisubstituted aziridines cis-1a2, $\mathbf{1 b} 3$ shown in the Scheme 2 [23].

More detailed studies of this AZ reaction were carried out in $2008[15,16]$. The structure of active catalyst was established [15]. This is a pyroborate 6 or $\mathbf{7}$ (Scheme 4). Reaction 
with a catalyst $\mathbf{6}$ and 7 (Scheme 4) has been explored in case of EDA 3a (Scheme 2) and 12 different imines 2a (Scheme 2), ee of the obtained 3-aryl aziridines 1a (Scheme 2) were in the range of $90-95 \%$.
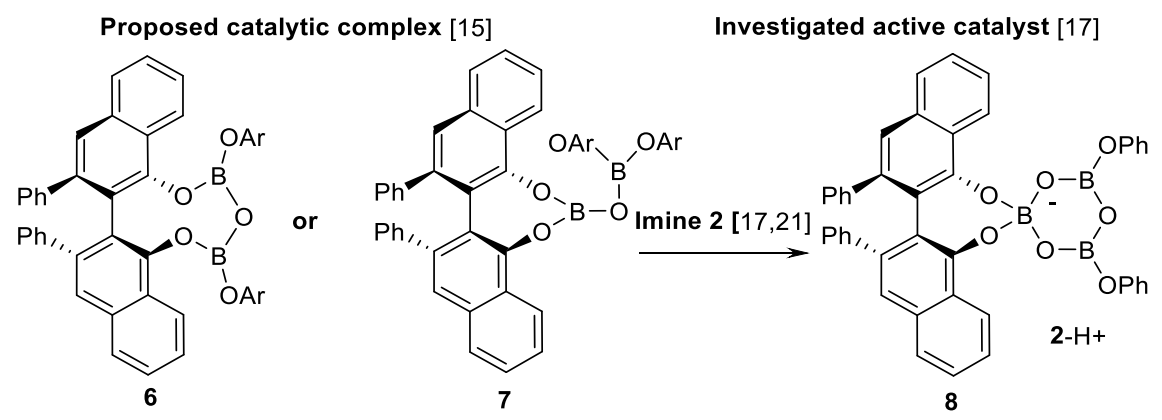

Scheme 4. Boroxinate catalyst $[15,17,21]$.

In the subsequent study [16], the active site of the aziridination catalyst "chemzyme" was explored using different $\mathrm{N}$-substituents in the imine 2a (Scheme 2), and authors found that 3.5-dimethyldianisilmethyl (MEDAM) and 3.5-di-tert-butyldianisilmethyl (BUDAM) groups resulted in the best asymmetric inductions in AZ reaction. Further, evidence of cyclic self-assembled boroxinate Brønsted acid ion pair $\mathbf{8}$ (Scheme 4) acting as an active catalyst in the asymmetric $\mathrm{AZ}$ reaction has been reported [17].

Control of diastereo- and enantioselection of chiral VAPOL/VANOL-based polyborate Brønsted acid catalyst-based AZ reactions has been studied [18,19]. In case of diazoamide $\mathbf{3 b}$, trans aziridines (Scheme 2; $\mathbf{1 b}$ ) can be obtained in reasonably high yields $(90 \%)$ and enantioselectivity reaching 96\% [18]. MEDAM group is the best imine 2a (Scheme 2) $\mathrm{N}$-substituent in this reaction. Also, cis aziridine amides $\mathbf{1 b}$ (Scheme 2) are obtained if the amide group is more sterically hindered [19]. Product stereochemistry-determining transition states have been studied both experimentally and in silico to obtain universal methodology of catalytic AZ reaction [19].

The previously described results have been summarized by Mukherjee et al. [21]. The $\mathrm{N}$-substituents have been compared, and it was found that MEDAM imines 2 (Scheme 2) showed $96-97 \%$ ee in resulting aziridines $\mathbf{1 a}, \mathbf{b}$ (Scheme 2). Imines $\mathbf{2 a}$ (Scheme 2) derived from seven different aryl aldehydes were examined in aziridine ester $\mathbf{1 a}$ and amide $\mathbf{1 b}$ (Scheme 2) synthesis.

Structure of the self-assembled boroxinate-imine complex 8 (Scheme 4) has been characterized by X-ray diffraction in case of two "chemzyme"-substrate complexes [22]. A practical gram-scale methodology of boroxinate Brønsted acid-catalyzed AZ reaction has been developed [24]. The further steps in developing this asymmetric aziridination tool were experiments with double stereodifferentiation using imines 2 (Scheme 2) obtained from chiral amines (chiral PG) [25] and one-pot five-component reaction protocol: Baseinduced formation of boroxinate catalyst 8 (Scheme 4) followed with subsequent addition of diazo compound 3 was replaced with simultaneous addition of all reagents [26].

The further increase of AZ reaction enantioselectivity was realized through insertion of substituents in $7,7^{\prime}$ positions of biaryl ligand $\mathbf{5 b}$ as depicted in the Scheme 3 [27]. Improving of catalyst ligand included developing of iso-VAPOL ligand $4 \mathbf{b}$ illustrated in the Scheme 3 [28]. This ligand was an isomer of VAPOL $4 \mathbf{a}$ (Scheme 3) but had a chiral pocket of VANOL 5a (Scheme 3) and was available from much cheaper starting materials.

In 2017, Wulff's group continued to study AZ reaction using closely related BINOL catalysts $\mathbf{9 a}$ and $\mathbf{9 b}$ represented in the Scheme 5 [29]. Different borate ester structures were investigated. Boroxinate $\mathbf{9 a}$ and spiro borate $\mathbf{9 b}$ (Scheme 5) yielded opposite asymmetric inductions in aziridine cis-1a1 (Scheme 2) formation. 
<smiles>CCOC(=O)C=N</smiles>

BINOL derived catalysts $[30,35,36]$<smiles>O=P(O)(NS(=O)(=O)Oc1c(Br)cc2ccccc2c1-c1cc2ccccc2cc1Br)C(F)(F)F</smiles>

$10 \mathrm{a}$<smiles>O=P(O)(O)Oc1c(Br)cc2ccccc2c1-c1cc(Br)cc2ccccc12</smiles>

$10 \mathrm{~b}$<smiles>O=C(O)c1c(Br)cc2ccccc2c1-c1c(C(=O)O)c(Br)cc2ccccc12</smiles>

$10 \mathrm{c}$

Scheme 5. Boroxinate and BINOL catalysts in AZ reaction [29-36].

A series (12 examples) of esters cis-1a1 (Scheme 2) were obtained by Thurston's group using BINOL-derived Brønsted acid catalyst 10a (Scheme 5) [30]. Multi-component variation of $\mathrm{AZ}$ reaction was carried out employing aromatic and heteroaromatic aldehydes. Other examples of multi-component $\mathrm{AZ}$ reaction approach involving the above mentioned VAPOL and BOROX catalysts are also known [31,32]. Optimal reaction protocol for aromatic aldehydes in synthesis of aziridines trans-1b (Scheme 2) was found [32].

Another boron Brønsted acid catalyst system-arylboronic acid $\mathbf{1 1}$ and chiral diol ligand 12 in situ assembled boronate ester (Scheme 6) was developed by Maruoka and coworkers [33]. Aziridine amides cis-1b3 (Scheme 6) were obtained in good yields and high enantioselectivities (22 examples). In case of $\alpha$-diazoacyl oxazolidinones $3 c$ (Scheme 6) as carbene sources and chiral $\mathrm{N}$-triflyl phosphoramide Brønsted acid catalyst 10a $(\mathrm{Ar}=\mathrm{Ph})$ [34] highly substituted oxazolidinone aziridine amides cis-1b4 (Scheme 6) were obtained in good (77-91\%) chemical yields and usually $>80 \%$ ee. Series of different 3-aryl substituents were demonstrated to be useful in these reactions in 24 examples. Reasonable trans-selectivity was reached in this type of reactions with chiral phosphoric acids $\mathbf{1 0 b}$ ( $\mathrm{Ar}=9$-Anthryl) [35] and 10c ( $\mathrm{Ar}=2.4 .6-\mathrm{Me}_{3}-\mathrm{C}_{6} \mathrm{H}_{2}$; Scheme 5) [36] as a catalyst to obtain amides trans-1b3 in excellent yields (89-97\%) and enantioselectivity (88-98\%), shown in 16 examples [35] and 14 examples [36], respectively. 


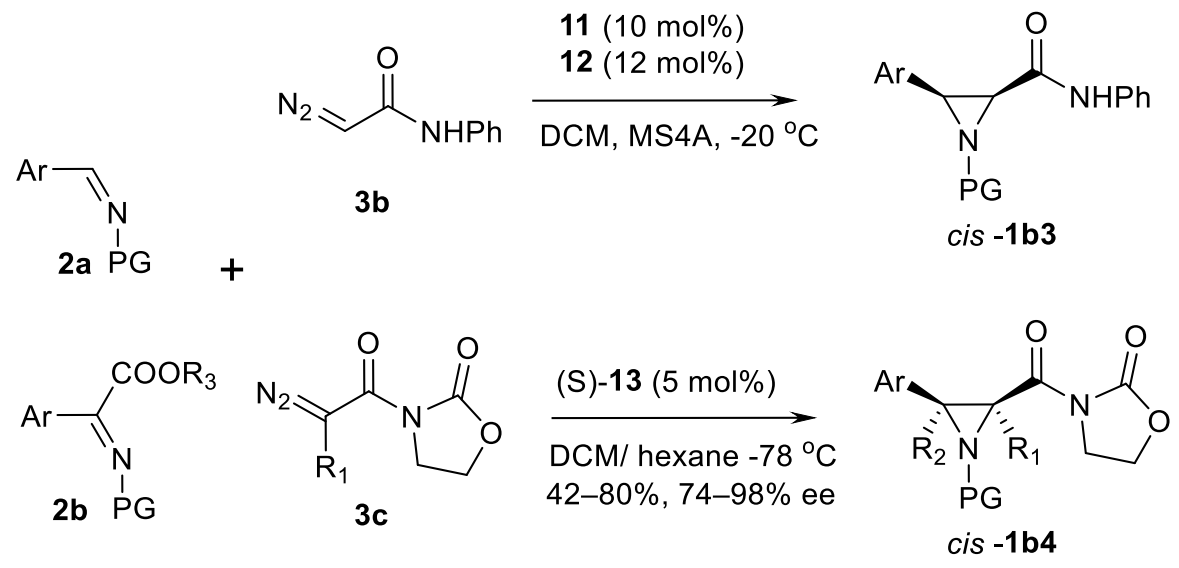

$\mathrm{R}_{1}=\mathrm{Me}, \mathrm{Et}, \mathrm{Pr}$

$\mathrm{R}_{2}=\mathrm{H}, \mathrm{COOR}_{3}$

$\mathrm{R}_{3}=\mathrm{Me}, \mathrm{Et}, t-\mathrm{Bu}$

$P G=B o c, B n[33]$

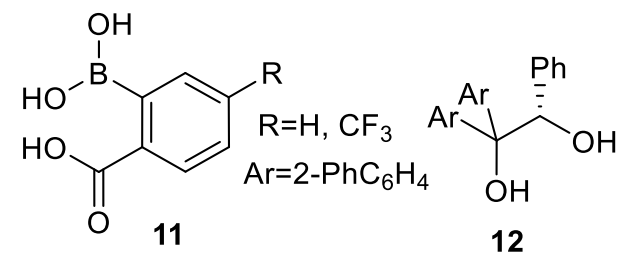

Scheme 6. AZ reaction with Maruoka's catalysts [33].

Enantioselective AZ reaction using another type of catalyst, namely, a ruthenium complex 13 (Scheme 7), was investigated by Mezzeti and co-authors [37,38].

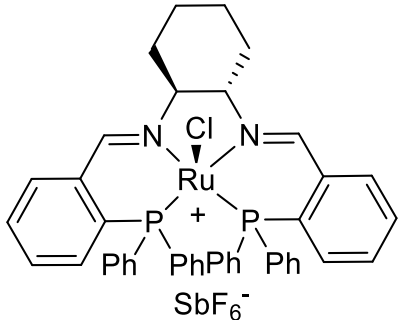

13

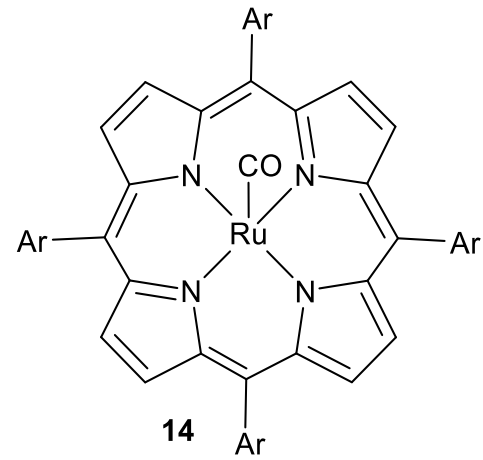

14

Scheme 7. Ruthenium catalysts for the AZ reaction [37-39].

Six examples of $\beta$-aryl esters cis-1a $\left(\mathrm{PG}=\mathrm{CHPh}_{2}\right)$ were demonstrated in moderate yields $(9-33 \%)$ and good ee $(75-93 \%)$. Another ruthenium complex (Scheme $7 ; 14)$ as a catalyst has been used in the same AZ reaction, leading to yields of esters cis-1a (16 examples) up to $86 \%$ [39] but the stereoselectivity was moderate, typically 2.5:1. Iron-pyBOX complexes [40] and rhodium-benbox complexes (ten examples [41]) as AZ reaction catalysts at room temperature were reported earlier, but results (yields, ee) were moderately good.

The use of a chiral diazonium compound (Scheme 8) represents an interesting asymmetric variation of $\mathrm{AZ}$ reaction $[42,43]$. Thus, $\mathrm{N}$ - $\alpha$-diazoacyl camphorsultams $3 \mathbf{d}$ demonstrate good results in reaction with imines $\mathbf{2 b}$ to obtain $\beta$-mono- and disubstituted aziridine2-carboxamides cis-1b4. 


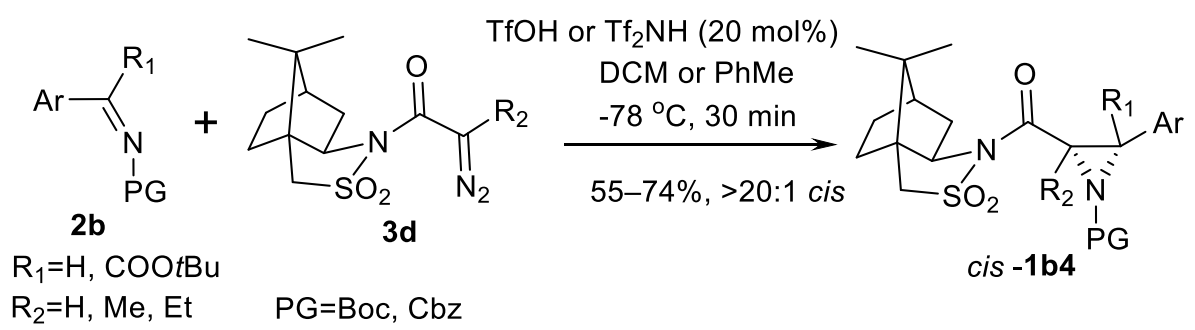

Scheme 8. Aziridination with a chiral diazonium reagent [42,43].

Diazoacetates 3e are useful substrates for synthesis of highly functionalized $\beta$-aryl aziridine ketoesters cis-1a3 as shown in the Scheme 9 [44]. Six successful examples with different arylimines were presented. Unfortunately, if $\mathrm{Ar}=p-\mathrm{NO}_{2} \mathrm{Ph}$, or 2-pyridyl, no reaction was observed. On the other hand, some examples of products cis-1a3 with another ester groups and 2.2-diesters instead of ketoester were demonstrated.

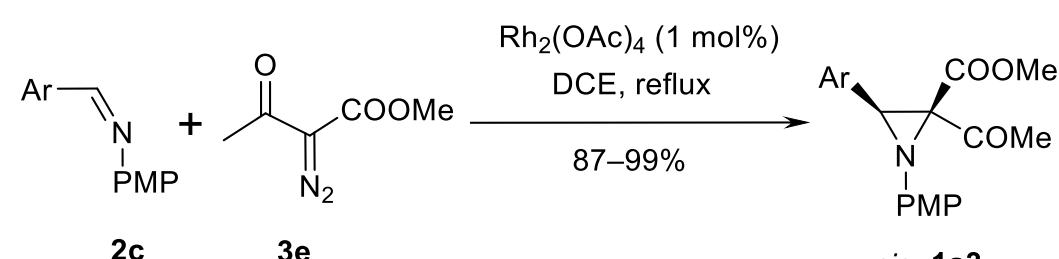

cis $-1 \mathbf{a} 3$

Scheme 9. Synthesis of 3-arylaziridine ketoesters [44].

Ionic liquids have been successfully tested for cis-selective AZ reactions [45,46]. Reac-

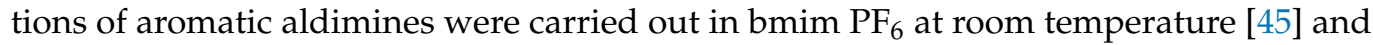
in the same liquids in multi-component variation with $2 \mathrm{~mol} \%$ of $\mathrm{Bi}(\mathrm{OTf})_{3}$ or $5 \mathrm{~mol} \%$ of $\mathrm{Sc}(\mathrm{OTf})_{3}$ catalyst [46] addition. The yields of aziridines cis-1a in both studies exceeded $80 \%$. Ten [45] and twelve [46] examples were demonstrated, respectively.

Other simple catalysts for imine $\mathrm{C}=\mathrm{N}$ bound aziridination with diazo compounds include $\mathrm{BF}_{3}{ }^{*} \mathrm{OEt}_{2}[47,48]$, montmorillonite $\mathrm{K}-10$ [49], $\mathrm{LiClO}_{4}$ [50] and $\mathrm{Rh}_{2}(\mathrm{OAc})_{4}$ [44,51]. The Lewis acid $\mathrm{BF}_{3}{ }^{*} \mathrm{OEt}_{2}$-catalyzed reaction of imino ester $\mathbf{2} \mathbf{d}$ and phenyldiazomethane 3f produces the aziridine ester cis-1a4 in good yield [47] without enamino- and dimeric byproducts (Scheme 10).

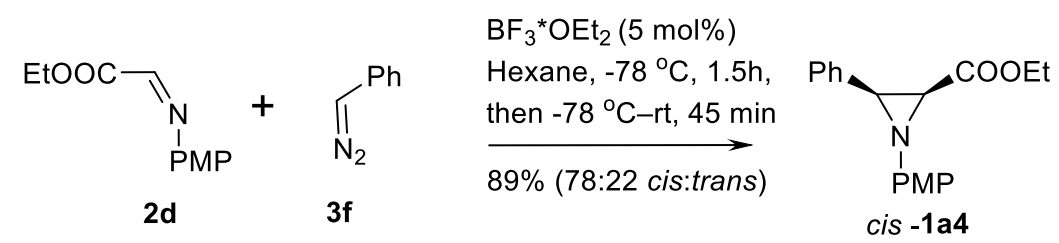

Scheme 10. Lewis acid-catalyzed aziridination [47].

Sugar-derived imine also was successfully aziridinated under $\mathrm{BF}_{3}{ }^{*} \mathrm{OEt}_{2}$ catalysis [48]. The montmorillonite K-10 catalysis in imine-EDA aziridine-forming reaction is characterised by high cis-selectivity and good yields ( 15 examples). The demonstrated procedure is very simple, namely, reactions were performed at room temperature with EDA as solvent [49]. A similar method with $\mathrm{LiClO}_{4}$ catalysis allows to obtain broad spectrum (18 examples) of 3-aryl aziridine esters cis-1a at room temperature in acetonitrile over $4.5-7.5 \mathrm{~h}$ at $>75 \%$ chemical yields and good stereoselectivity [50].

Organocatalytic variations of AZ reaction are also known. In presence of pyridinium salts as Brønsted acid organocatalysts cis-selective synthesis of esters cis-1a was demonstrated [52,53]. The best results show $10 \mathrm{~mol} \%$ of pyridinium triflate [53]. Synthesis of 21 examples of different 3-aryl aziridine-2-carboxylates 1a bearing substituted phenyls and 2-pyridils in $\beta$-position has been demonstrated (70-99\% yields). Polymer-supported 
pyridinium salt also was reported as an effective catalyst (80\% yield of product), and three-component one-pot process was performed.

In addition, $\mathrm{N}$-fluoropyridinium triflate (fluoronium ion catalyst) has been described as an organocatalyst in eight examples of these reactions [54], and the reached results were comparable with the previously listed examples. A source of cation radical, tris-(4bromophenyl) aminium hexacloroantimonate $\left(\mathrm{TBPA}^{+} \mathrm{SbCl}_{6}{ }^{-}\right)$, was an effective initiator of EDA $3 \mathbf{a}$ addition to aryl imines 2 in 13 examples [55]. tert-Butyl diazoacetate addition to onepot-generated aldimines 2 under pyridinium triflate catalysis was successfully employed to obtain more complex 3-aryl aziridine structures 1a5, 1a6 shown in the Scheme 11 [56].

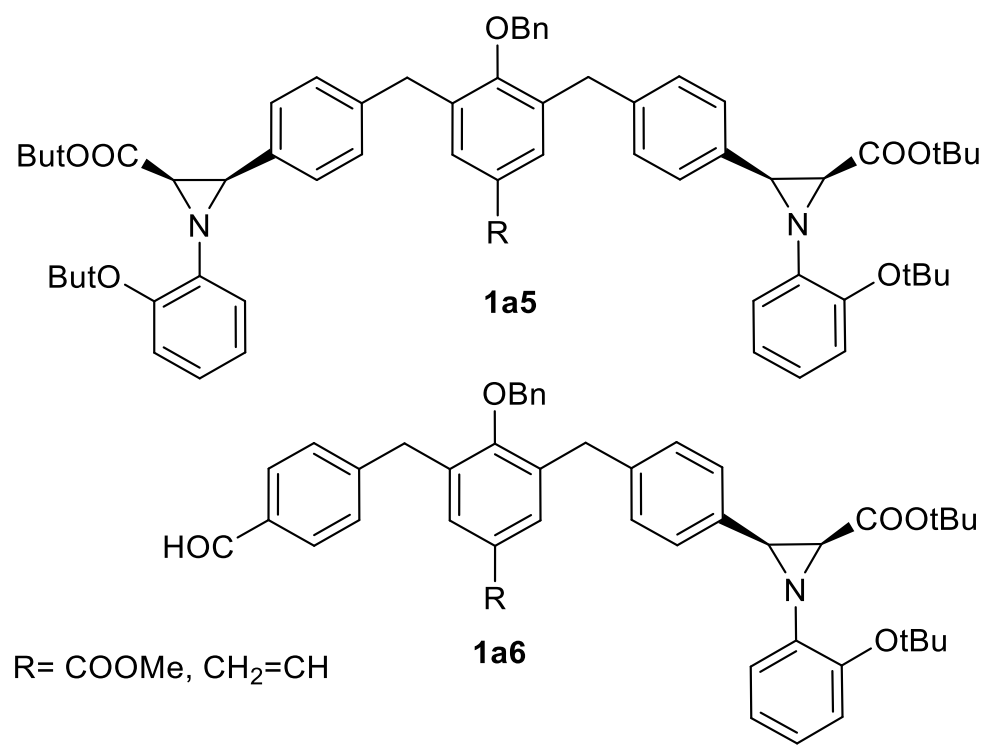

Scheme 11. Pyridinium triflate-catalyzed aziridination products [56].

An interesting variation of imine aziridination was EDA-aziridination of in situ generated iminium ion [57], generated from $\alpha$-aminonitriles.

\subsection{Aziridination of Imines with Other Carbene Precursors}

Other carbene precursors or carbene-like species can be added to imines. These species include:

- Active methylene compounds;

- Enolates derived from $\alpha$-bromoesters and bases;

- Lithiated enamines;

- Guanidinium, ammonium or sulfonium ylides.

\subsubsection{Variations of $a z a$-Darzen Reaction}

The most frequently used method is the addition of enolates derived from $\alpha$-bromoesters to various imines ( $a z a$-Darzen reaction variations).

The sources of chirality are chiral $\mathrm{N}$-substituents in imines or enolates. Use of chiral enolates and $\mathrm{N}$-diphenylphosphinylimines were explored by Sweeney and co-authors $[58,59]$. Thus, enolate 16a, generated from $2 R$-N-bromoacethylcamphorsultam 15a (Scheme 12) reacts with $\mathrm{N}$-diphenylphosphinyl aldimines $\mathbf{2 e 1}$ leading to 3-arylaziridine-2-carboxamides cis-1b5. 


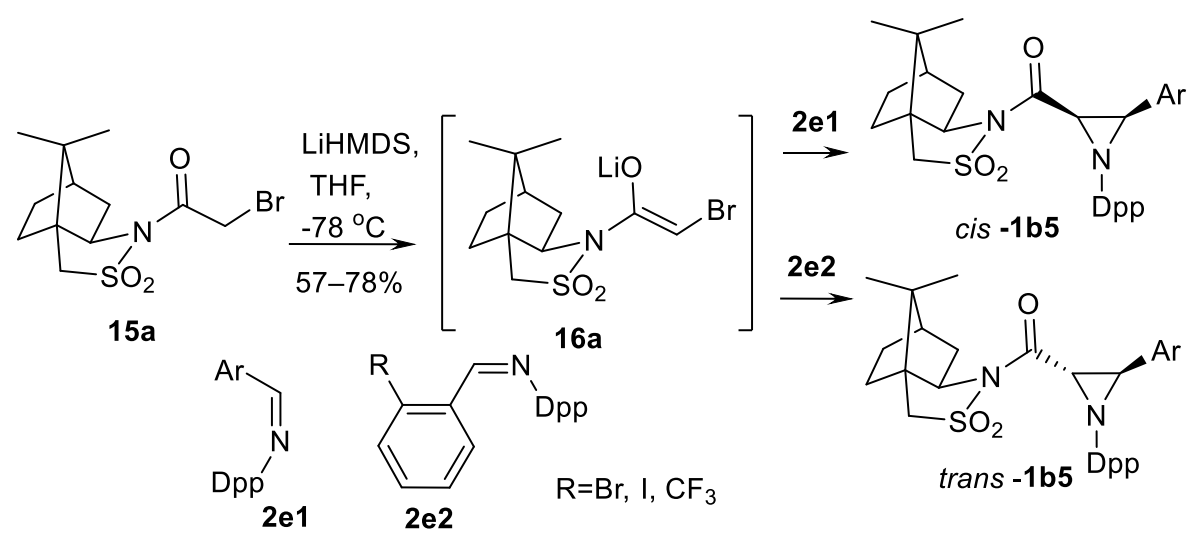

Scheme 12. Sweeney's aza-Darzen type aziridination $[58,59]$.

Chemical yields are good (57-78\%) and stereoselectivity excellent, $>95 \%$ dr in 14 demonstrated examples [58]. However, in some cases depending of the imine aryl substituent structure (using imines 2e2) inversion of stereochemistry has been observed and aziridines trans-1b5 obtained [59]. The mechanism of reaction and transition states were elucidated.

Another approach to chiral 3-aryl aziridine-2-carboxylic acid derivatives by asymmetric aza-Darzen type reaction is the use of chiral moiety in the imine component.

There are chiral N-phosphinyl imines 2f1, 2f2 [60,61] and chiral sulfimines 2f3, 2f4 [62-64] presented (Scheme 13). N-phosphinyl imines $\mathbf{2 f 1}$ have been successfully used in $a z a$-Darzen reaction with enolates generated from esters $\mathbf{1 5 b}$ in ten examples of aziridines cis-1a7 in $72-82 \%$ chemical yields and $>80 \%$ de [60]. Better results have been achieved by imines $2 \mathbf{f} 2$ : 17 examples of aziridines cis-1a7 with various 3-aryl substituents and four examples of different esters $1 \mathrm{a} 7(\mathrm{Ar}=\mathrm{Ph})$ have been obtained in good chemical yields $(51-87 \%)$ and $>98 \%$ cis- selectivity [61]. Chiral tert-butanesulfinyl aldimines $\mathbf{2 f 3}, \mathbf{2 f 4}$ and ketimines $2 \mathbf{f 5} 5$ were used in series of aziridines cis-1a7 synthesis [62]. Corresponding 3-aryl and 3.3-diaryl products were obtained in moderately good cis-selectivity (71:29-98:2); eight examples of 3-aryl products cis-1a7 were demonstrated. Isolated examples of S-mesitylsulfinyl imines $\mathbf{2 f 4}$ have been employed in aziridine cis-1a7 synthesis [63]. Trisubstituted 3-aryl aziridine-2-carboxylates cis-1a7 were obtained from substituted 2-bromoesters $\mathbf{1 5 b}$ and tert-butane sulfinyl aldimines $\mathbf{2 f 3}$ [64] in $>60 \%$ chemical yields and $>98 \%$ de (five examples).

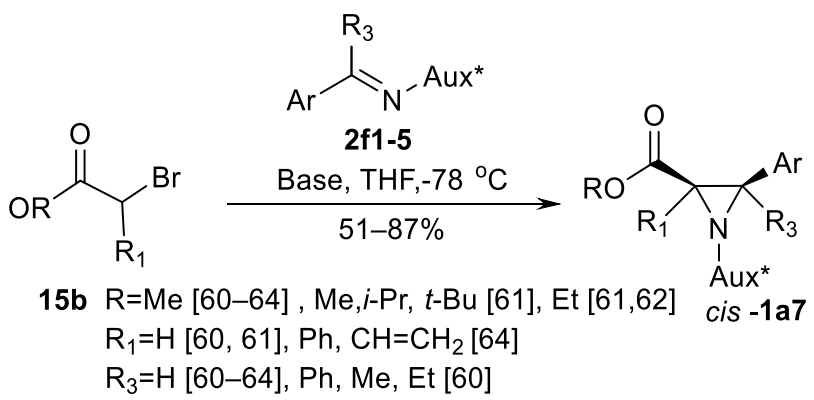

Aux*:

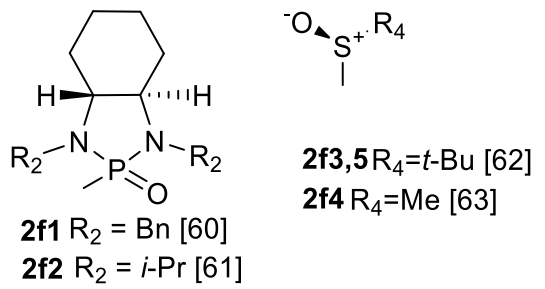

Scheme 13. aza-Darzen aziridinations with chiral imines [60-64].

Modified aza-Darzen type protocol allows to obtain trisubstituted spirocyclic 3-aryl aziridinyl ketones 1c3 (Scheme 14) from cyclic halogenated ketones 15c illustrated in the 
Scheme 14 [65]. Two protocols-one-step direct approach to ketones 1c3 (Scheme 14) and two-step synthesis through an addition product, namely, tertiary halogenide $\mathbf{1 6}$ (Scheme 14) -were realized. Chloro- and bromoketones 15c (Scheme 14) were used, and the catalyst was Zn-ligand 17 (Scheme 14) complex. Reactions can be run in gram-scale with small amounts of catalyst. Chemical yields of products (30 examples) are $75-99 \%$ in $>20: 1 \mathrm{dr}$.

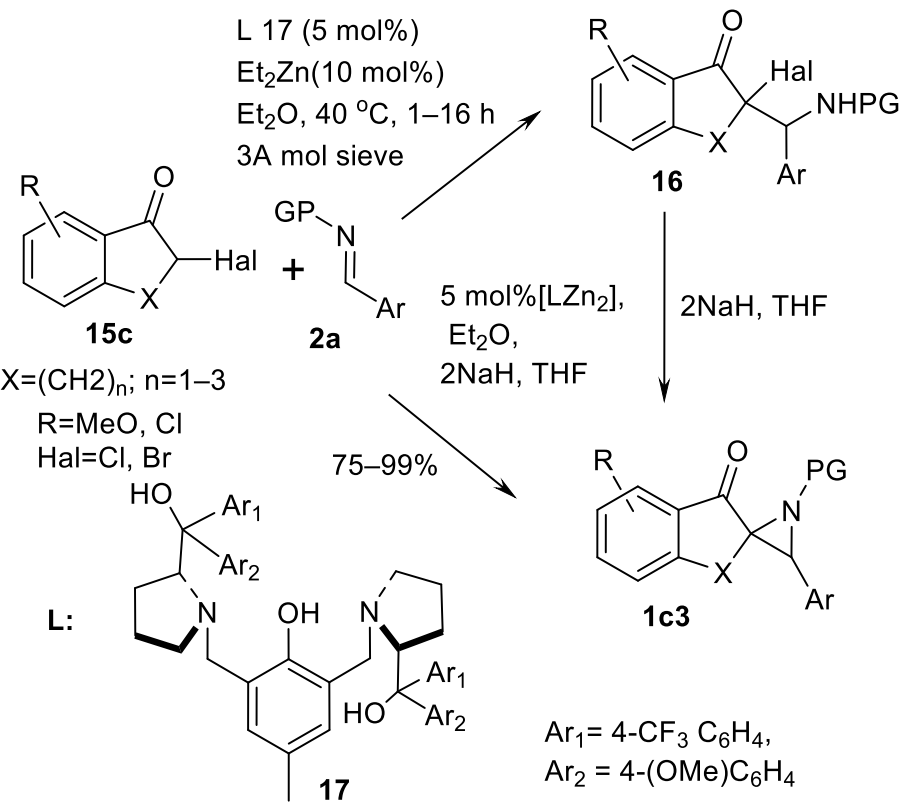

Scheme 14. Spirocyclic aziridine products via aza-Darzen aziridination [65].

In a similar way, $\alpha$-chloro-1.3-diketones 1c4 (Scheme 15) were used as enolate precursors in $a z a$-Darzen type synthesis [66] in reactions with N-benzoylarylaldimines $\mathbf{2 a 1}$ under $(R)$ VAPOL magnesium phosphonate salt catalysis (Scheme 15). In case of electron deficient imines 2a (Scheme 15), no strong bases are necessary and aziridines 1c4 (Scheme 15) form in $52-78 \%$ yield and $57-92 \%$ ee.

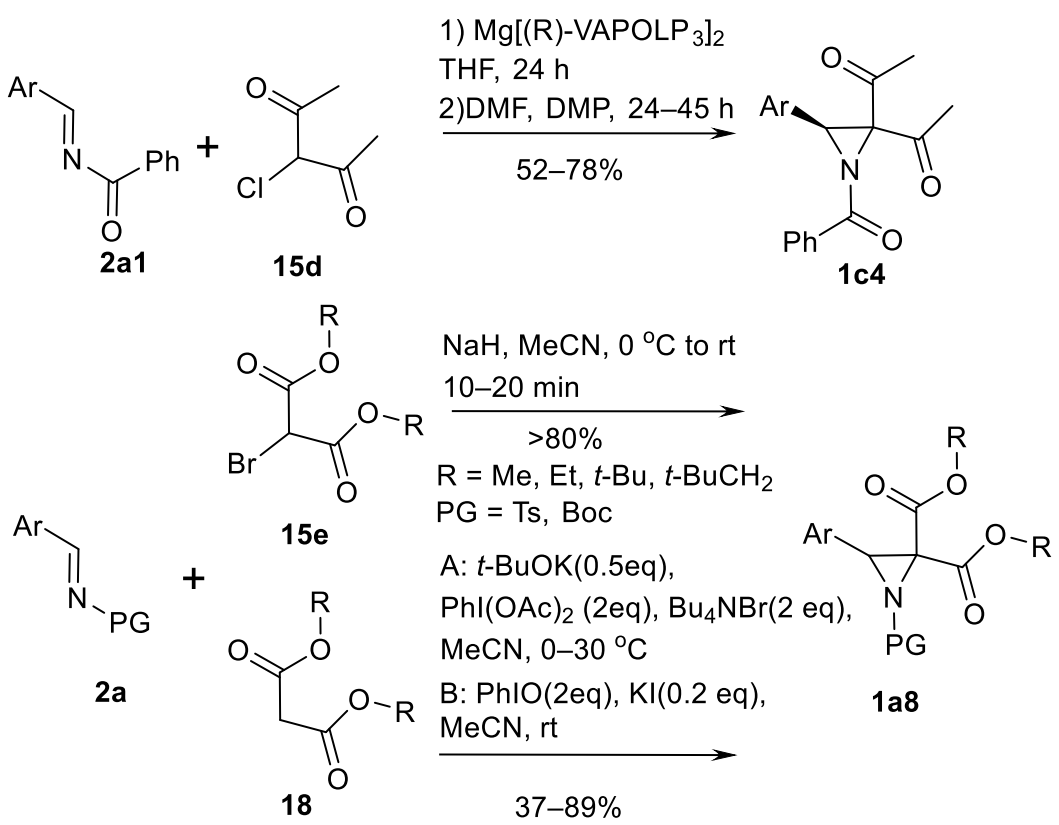

Scheme 15. Diketones and diesters in $a z a$-Darzen aziridination [66-69].

3-Arylated aziridine diesters 1a8 (Scheme 15) also can be prepared in aza-Darzen reaction [67]. Racemic aziridines $1 \mathbf{1 a} 8$ (Scheme 15) are obtained in $>80 \%$ yields from imines 
2a (Scheme 15) and bromomalonates 15e (Scheme 15). Useful N-substituent for these reactions was tosyl (24 examples) but N-Boc aziridine diester 1a8 (Scheme 15) also can be prepared from N-Boc imine $\mathbf{2 a}$ (Scheme 15). N-tosyl imines $\mathbf{2 a}$ (Scheme 15) can react with activated methylene compounds $\mathbf{1 8}$ (Scheme 15) in iodine (III) induced aziridinations to form aziridines $\mathbf{1 a 8}$ as shown in the Scheme 15 [68,69]. Iodobenzene diacetatetetrabutylammonium bromide system was reported first [68]. Aziridines 1a8 (Scheme 15) can form from malonates $\mathbf{1 8}$ (Scheme 15), acetyl-, cyano- and nitroacetic acid esters to obtain symmetrical and unsymmetrical products 1a8 (Scheme 15) in 37-89\% yields. The further study showed that PhIO-KI system is a better oxidative iodine (III) additive for these reactions [69]. In this case, aziridines $1 \mathbf{a} 8$ (Scheme 15) are obtained in $>75 \%$ yields.

Reformatsky type aza-Darzen reaction variation using imines $\mathbf{2 a}$, inactivated zinc metal and fluorodibromoacetate $\mathbf{1 5 f}$ is successfully used for access to 3-arylated 2-fluoro aziridine-2-carboxylates 1a9 as shown in the Scheme 16 [70].

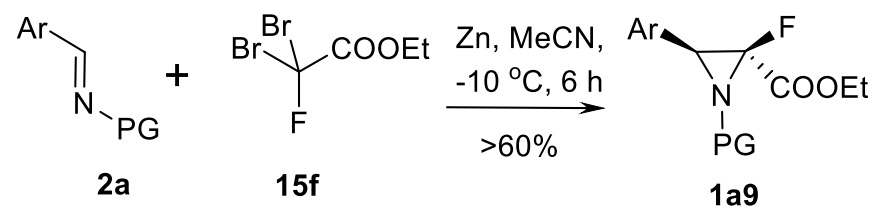

Scheme 16. Reformatsky type aza-Darzen aziridination [70].

Yields up to $60 \%$ (determined by ${ }^{19} \mathrm{FNMR}$ ) and up to $80 \%$ syn products were obtained in ten examples.

More complicated cascade reactions (Scheme 17) which allowed stereoselective obtaining of 3-arylated 2-chloro aziridines was demonstrated by $\mathrm{Xu}$ and co-authors [71]. This cascade coupling included nucleophilic addition of anion generated from silyldichloromethane 20 and nitriles 19 in presence of LDA and subsequent [1,3] -aza-Brooke rearrangement to give $\alpha-\mathrm{N}$-silyl imines in equilibrium with 1 -azaenolate equivalents. These species were then trapped by imines $\mathbf{2 g}$ in an $a z a$-Darzen type reaction to give aziridines $\mathbf{1 c 5}$ in good (up to 50\%) yields and up to 10:1 selectivity demonstrated in 19 cases for each method. Remarkably, stereoselectivity strictly depends on the silyl group and the order of addition of $2 \mathrm{~g}$ and HMPA (method A or B).

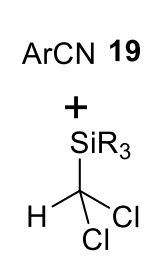

20<smiles>[3H]/C=N/S(=O)C(C)(C)C</smiles>

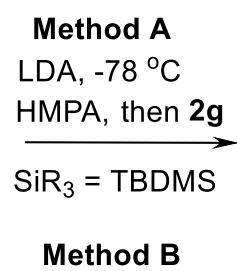

LDA, $-78^{\circ} \mathrm{C}$

2g, then HMPA<smiles>[AsH3]</smiles>

$>50 \%$

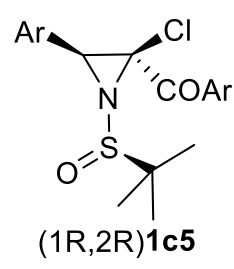<smiles>[CH][C@H]1[C@H](Cl)N1S(=O)C(C)(C)C</smiles>

$(1 \mathrm{~S}, 2 \mathrm{~S}) 1 \mathrm{c} 5$

Scheme 17. Cascade aziridination examples [71].

\subsubsection{Ylides as Carbon Sources}

An interesting variation of $\mathrm{C}=\mathrm{N}$ double-bond aziridination are aziridinations of ylides. The first remarkable reports were made by Ishikava's group on reactions of guanidinium ylides with aryl aldehydes as a practical route for obtaining of inactivated 3-arylated aziridine-2-carboxylates 1a1 [72-76]. The initial study [72] for the first time reported the formation of guanidinium ylides $\mathbf{2 1} \mathbf{b}$ from guanidinium salts $21 \mathbf{a}$ in the presence of base $(\mathrm{NaH}$ or tetramethylguanidine) and their reactions with aryl aldehydes to form trans aziridines 
1a1 (Scheme 18). In the subsequent publication [73], the potential reaction mechanism and role of the $p$-substituents in aldehyde aryl ring were explored. The authors concluded that in the case of EDG $p$-substituted benzaldehydes $S_{N}$ i-like mechanism and in case of EWG substituents $S_{\mathrm{N}}$ 2-type mechanism took place. Not only trans aziridines $\mathbf{1 a 1}$ are available with this method. Procedure of epimerization in $\beta$ - (C3) position was described [74] using indium chloride catalyst. Aziridinomitosene skeleton synthesis [74], formal synthesis of (-)-podophyllotoxin [75] and synthesis of cyclic dipeptide (-)-benzolactam-V8 [76] has been demonstrated.

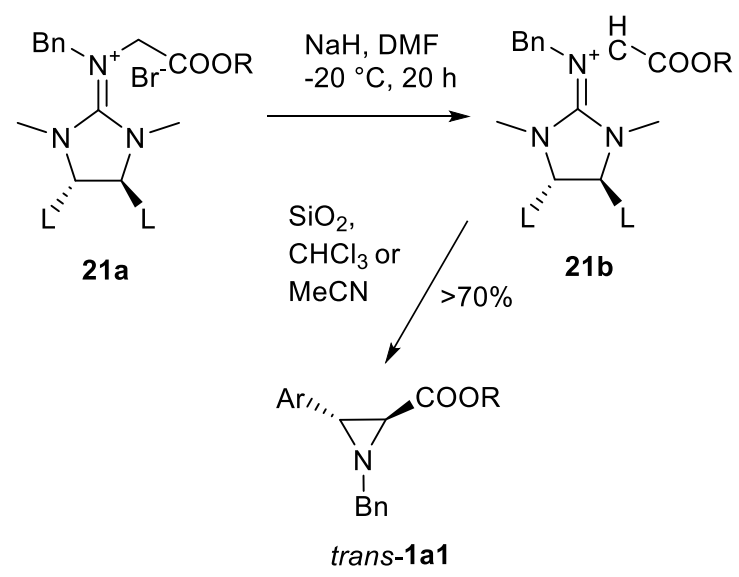

Scheme 18. Ishikava's aziridination [72-77].

Finally, reaction conditions were optimized, the method was expanded to broad spectrum of aryl aldehydes (45 examples) and series of modified guanidine salts were examined to reach a general method for highly substituted 3-arylaziridine-2-carboxylate 1a1 synthesis [77].

Other ylides can work in a similar way. Thus, aziridinations via ammonium [78-80] and sulfonium [81-84] ylides are known. A simple protocol for the reaction of phenacyl bromides $\mathbf{1 5} \mathrm{g}$ with imines $\mathbf{2 a} 2$ promoted by tertiary amine (DABCO) via in situ generated ylide (Scheme 19) has been reported [78].

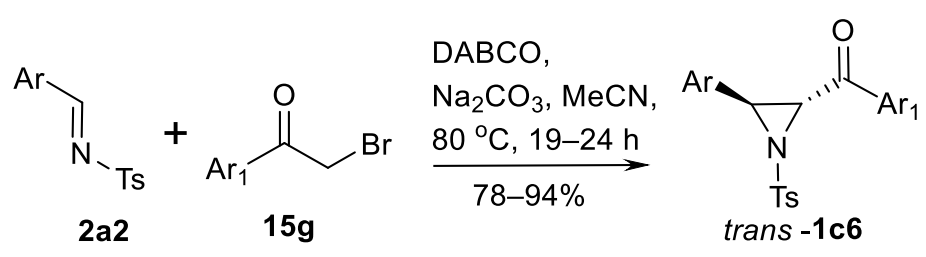

Scheme 19. DABCO-promoted aziridination [78].

This one-pot aziridination process include quaternization of DABCO, then in situ formation of ammonium ylide in the presence of base and aziridination of imine $\mathbf{2} \mathbf{a} \mathbf{2}$ to obtain 3-arylated trans-aziridinyl ketones trans-1c6 in good yields (nine examples) and trans-selectivity. Enantioselective aziridination using chiral DABCO analogue also was demonstrated.

Simple trimethylammonium salts work similarly via amide-stabilized ammonium ylides (forming from salts 22a; Scheme 20) which react with aromatic aldimines $\mathbf{2 a} 3$ to form 3 -arylated trans-aziridine carboxamides trans-1b [79]. Moderate to good yields and transselectivity has been demonstrated in eight examples. Remarkable feature is that ammonium salts $\mathbf{2 2} \mathbf{b}$ do not react with aldimines $\mathbf{2 a} 2$ in similar way. However, the classic $a z a$-Darzen process-reaction of imines $\mathbf{2 a} 2$ with phenacyl bromide $\mathbf{1 5 g}$-gives cis-aziridinyl ketones cis-1c6 in high yields. 


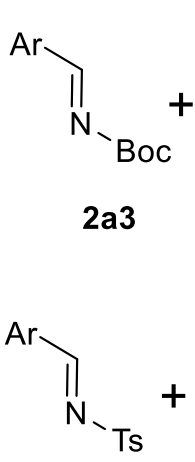

$2 \mathrm{a} 2$<smiles>N#CCC(=O)OCc1ccccc1</smiles>

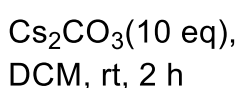
$\mathrm{DCM}, \mathrm{rt}, 2 \mathrm{~h}$

$49-75 \%$

$\mathrm{R}=\mathrm{Et}, \mathrm{Ph}, \mathrm{Bn}$, piperidine<smiles>CC(C)(C)C(C)(C)C</smiles>

$\mathrm{Cs}_{2} \mathrm{CO}_{3}(1 \mathrm{eq})$, DCM, rt, $2 \mathrm{~h}$<smiles>O=C(CBr)c1ccccc1</smiles><smiles>[R20]C(=O)[C@@H]1[C@@H]([TeH])N1[R6]</smiles>

trans $\mathbf{- 1 b}$<smiles>O=C(c1ccccc1)C1[C@@H]([AlH2])N1[AsH2]</smiles>

Scheme 20. Ammonium salt-promoted aziridination via ylides [79].

Asymmetric aziridination using stabilized trimethylammonium salts 23 has been demonstrated [80] in six examples (Scheme 21). Aziridine carboxamides trans-1b6 were obtained in good yields.

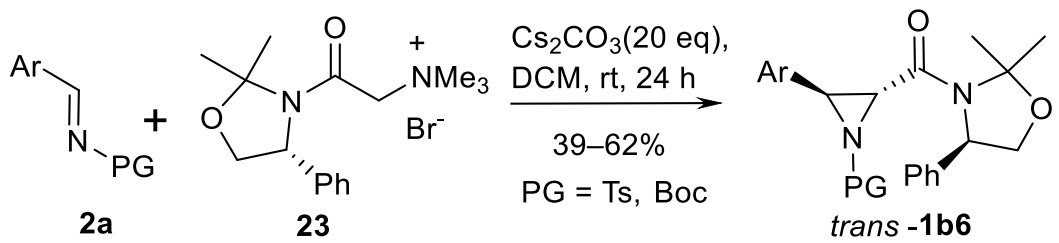

Scheme 21. Aziridination with chiral stabilized trimethylammonium salt [80].

Sulfonium ylide-mediated catalytic asymmetric aziridination of imines were mentioned by Aggarwal's group [81,82]. Chiral sulfides, for example, 24 and catalytic amounts of metal salts, promote aziridination of imines with diazo compounds via sulphur ylide intermediates (Scheme 22). Five examples of synthesis of aziridines trans-1a, $\mathbf{b}$ were demonstrated reaching good yields (53-98\%) and moderate enantioselectivity of 30-58\% ee [81].

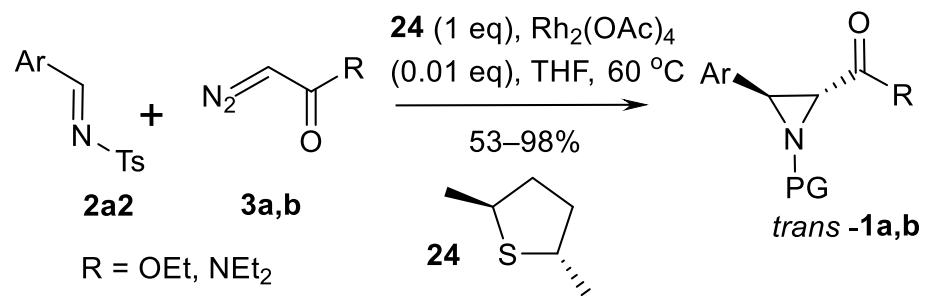

Scheme 22. Aggarwal's aziridination $[81,82]$.

Ester and amide-stabilized sulfur ylides generated form sulfonium salts were explored [82] as sources of aziridines (Scheme 23). It was established that ester and amidestabilized sulfur ylides 25 react with activated aryl aldimines $\mathbf{2 a 2}$ reversibly to form betaines $\mathbf{2 6}$ and the stereocontrolling step is represented by the base-controlled aziridine ring closure leading to aziridines $\mathbf{1 a 6}, \mathbf{1 b 6}$. 


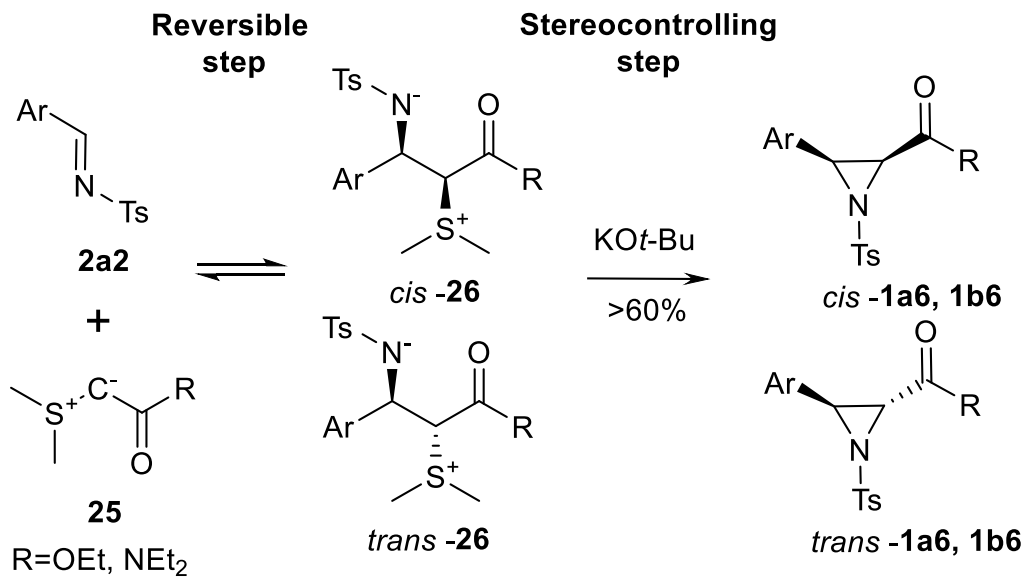

Scheme 23. Sulfur ylide aziridination [82].

A series of 3-arylated N-diphenylphospinoyl aziridine-2 carboxamides trans-1b7 are synthesized in similar route from amide sulfonium salts via type 25 stabilized ylides [83] as well as series of chiral 3-aryl spiro-aziridine oxindoles $\mathbf{1 b 8}$ (11 examples, 60-76\%, $\mathrm{dr}>$ 99:1) from corresponding imines using ylides generated from sulfonium salts in presence of $\mathrm{NaH}$ (Scheme 24) [84]. Therefore, sulfonium ylides as well as the above mentioned guanidinium and ammonium ylides are useful tools in target aziridine synthesis.<smiles>CNC(=O)[C@@H]1[C@@H]([AlH2])N1P(=O)(c1ccccc1)c1ccccc1</smiles>

trans $\mathbf{- 1 b 7}$<smiles>[R]c1cccc2c1N(C)C(=O)[C@@]21[C@H]([13CH3])[C@H]1S(=O)C(C)(C)C</smiles>

$1 \mathrm{~b} 8$

Scheme 24. Sulfur ylide aziridination products [83,84].

An interesting variation of aziridine synthesis from imines is the benzyne-promoted Darzen-type reaction of tertiary amine 27 as shown in the Scheme 25 [85]. This process was performed in mild conditions (no strong bases, room temperature) in the presence of 2-(trimethylsilyl)phenyl triflate 28, KF and a crown ether. Five different 3-arylated aziridine-2-carboxylates trans-1a1 were obtained in moderate to good yields (40-80\%) and good trans-selectivity $>98: 2 \mathrm{dr}$.

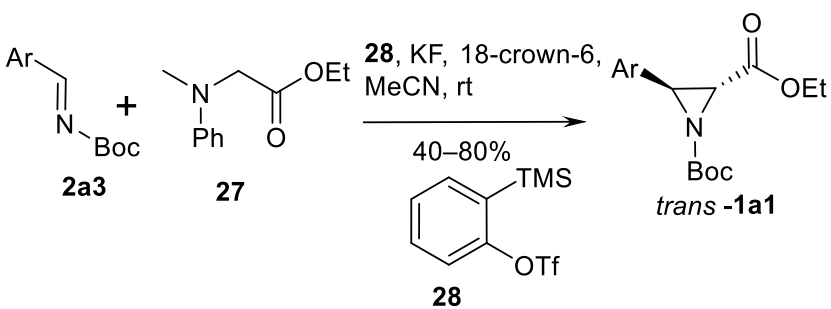

Scheme 25. Benzyne-promoted Darzen-type aziridination [85].

\section{Aziridination of Olefins (Path B)}

This pathway of aziridination includes:

- Evans aziridination with arylsulphonyliminophenyliodinanes;

- Oxidative aziridination with N-aminophtalimide and its analogues;

- Active hydroxylamines as aminating agents. 


\subsection{Evans Aziridination}

The reaction of olefins with active nitrene species generated from various nitrene precursors represents another well-known and reliably explored method to synthesize aziridine structures 1 . The first approach, notable for 3-aryl aziridine-2-carboxylic acid derivative synthesis, is the classical Evans aziridination using PhI=NTs as nitrene precursor, cinnamate type substrates $\mathbf{2 9}$ as olefins in the presence of $\mathrm{Cu}$ salts as catalysts (Scheme 26) [86,87].

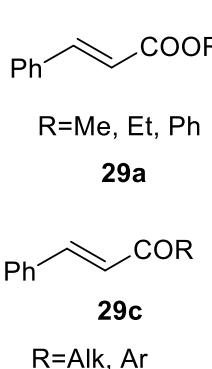

$\mathrm{R}=\mathrm{Alk}, \mathrm{Ar}$

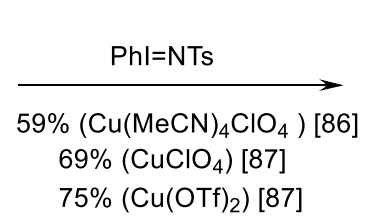<smiles>CC(C)(C1=NC(c2ccccc2)CO1)C1=N[C@@H](c2ccccc2)CO1</smiles>

$30 \mathrm{a}$ [88]<smiles>[14CH3]N1C(C(=O)O)C1c1ccccc1</smiles><smiles>[R]C(=O)[C@@H]1[C@@H](c2ccccc2)N1[13CH3]</smiles>

Scheme 26. Evans aziridination [86-89].

Other nitrene precursors ( $p$ - $\mathrm{NO}_{2}$ and $p$-OMe benzenesulphonylimino-phenyliodinanes instead of $\mathrm{PhI}=\mathrm{NTs}$ ) may increase yields of 29a type cinnamate aziridinations products $\mathbf{1 a 1 0}$ to $97 \%$ in $87 \%$ ee using chiral ligand 30a (BOX) [88]. Aziridination using iodosylbenzene in combination with sulfonylamides instead of iminoiodinanes has been reported, but the yields of 1a type esters were only moderately high reaching $40-53 \%$ [89].

The further investigations in Evans aziridination included various design of chiral ligands (Scheme 27). Thus, a series of cinnamates were aziridinated using copper-catalyzed asymmetric aziridination with $\mathrm{PhI}=\mathrm{NTs}$ and chiral salen type ligand $\mathbf{3 1}$ (nine examples, yield $60-90 \%, 61-93 \%$ ee) [90] as well as binaphthyldiimine ligand 32 (11 examples, yield $47-92 \%, 11-97 \%$ ee) [91]. A series of cinnamates and chalcones has been successfully aziridinated by $\mathrm{PhI}=\mathrm{NTs} /\left[\mathrm{Cu}(\mathrm{MeCN})_{4}\right] \mathrm{PF}_{6}$ system in the presence of the same ligands 32 ( $R$ and $S$ BINIM-DC) (15 examples, yields $41-87 \%, 36-97 \%$ ee) [92].

Similarly, biaryl Shiff base 33 was used as a ligand (nine examples, yield $32-77 \%$, 89-98\% ee) [93]. Aziridine esters trans-1a have been obtained, and structures of copperligand 32 complexes [93] and reaction mechanisms [94] have been explored. The improved diimine ligand 34 was used in asymmetric aziridination of cinnamates under $34 / \mathrm{Cu}(1)$ catalysis with $\mathrm{PhI}=\mathrm{NTs}$ as nitrene source (yield $63-99 \%,>80 \%$ ee) or in a one-pot procedure with iodobenzene diacetate-sulfonamide system [95].<smiles>Clc1cccc(Cl)c1C=Nc1ccc2c(c1-c1c(Cl)cccc1Cl)CCCC2</smiles><smiles>Clc1cccc(Cl)c1C=Nc1ccc2ccccc2c1-c1c(Cl)ccc2ccccc12</smiles><smiles>Cc1cccc(/N=C\c2c(Cl)cccc2Cl)c1-c1c(C)cccc1/N=C/c1ccccc1Cl</smiles><smiles>CC1(C)CC(/N=C/c2c(Cl)cccc2Cl)C(C2OC(C)(C)CC2/N=C/c2c(Cl)cccc2Cl)O1</smiles>

Scheme 27. Chiral ligands for Evans aziridination [90-92,95]. 
The next well-explored group of chiral ligands for Evans-type aziridination of olefins that are used in synthesis of 3-arylaziridine-2-carboxylic acid derivatives 1a are bidentate bis-oxazolinyl type compounds-the analogues of BOX ligand 30a mentioned above [88]. The further development of such ligands are 1.8-bisoxazolinylanthracene (AnBOX) type ligands 30b [96,97] and cyclohexane-linked bis-oxazolines 30c (cHBOX) shown in the Scheme 28 [98]. The AnBOX ligand 30b was successfully used in asymmetric aziridination of chalcone type substrates 29c with $\mathrm{PhI}=\mathrm{NTs}$ in CuOTf catalysis to obtain aziridinyl ketones trans-1c (nine examples, yields 51-91\%, 68-99\% ee) [96].<smiles>CC(C)[C@H]1COC(c2cccc3cc4cccc(C5=N[C@@H](C(C)C)CO5)c4cc23)=N1</smiles>

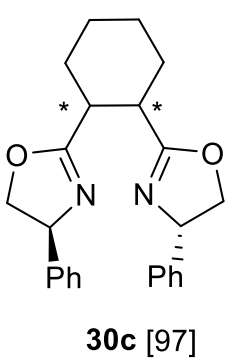

Scheme 28. AnBOX and cHBOX ligands [95-97].

In a subsequent, more detailed study [97] the substrate scope was expanded (22 chalcone and a single cinnamate substrate example, yield 35-92\%, 27-99\% ee) and the limitations explored. Higher enantioselectivity in the chalcone aziridination has been reached using (S)-cHBOX 30c (11 examples, yield 51-73\%, >80\% ee) [98].

The comparison of BOX 30a, AnBOX 30b and cHBOX 30c ligands in Evans-type chalcone substrate 29c aziridination and the exploration of $\pi$-stacking between chalcone and ligand aromatic systems were performed [99]. The results showed that $\pi$-interaction between chalcone substrates 29c and the AnBOX ligand's 30b anthracene backbone was important in order to improve the enantioselectivity of aziridination.

The further improvements of Evans chalcone 29c and cinnamate 29a aziridination included use of $\mathrm{Cu}(2)$ and poly/perfluorinated alkoxyaluminate type anion complexes [100], alumina-supported [101] and immobilized magnetic $\mathrm{Cu}$ containing nanoparticles [102]. Use of gold instead of copper catalyst has also been reported [103].

In conclusion, Evans aziridination is a practical method for the synthesis of trans3-arylated aziridine-2-carboxylates 1a and aziridin-2-ylketones 1c from corresponding cinnamates 29a and chalcones 29c, respectively.

\subsection{Oxidative Aziridination}

Another important method for asymmetric aziridination of alkenes is the reaction with $\mathrm{N}$-aminophthalimide in the oxidative conditions $\left(\mathrm{Pb}(\mathrm{OAc})_{4}\right.$ or another oxidant) as a nitrene source. The asymmetric induction can be conducted with chiral moiety in the substrate and with chiral ligand. Thus, use of chiral auxiliary can be illustrated by aziridination of chiral camphor N-enoylpirazolidinone $\mathbf{2 9 b 1}$ to obtain aziridine-2-hydrazide trans-1b9 (Scheme 29) in good yield [104]. Another chiral camphor-based auxiliary-directed aziridination of aziridine esters was demonstrated [105] but this study was focused on only a single example of cinnamate 29a.

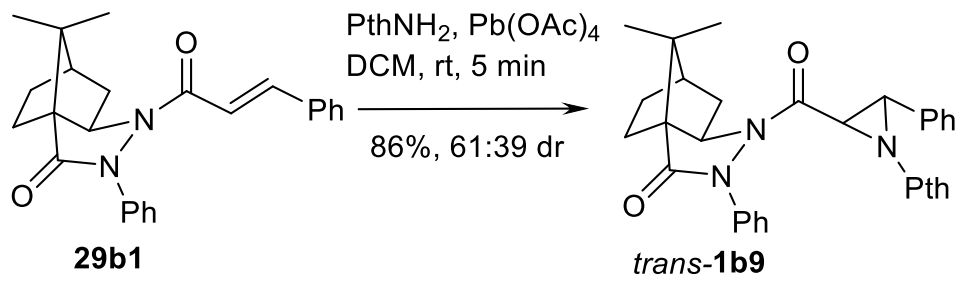

Scheme 29. Oxidative aziridination of a chiral substrate [104]. 
Chiral ligand-mediated variation of this aziridination was studied by the same authors [106]. Reaction of N-enoyl oxazolidinones $\mathbf{2 9} \mathbf{b} 2$ in similar conditions and in presence of ligand $\mathbf{3 5}$ lead to aziridine-carboxamides trans-1b10 in good yields and $>80 \%$ ee (Scheme 30 ).
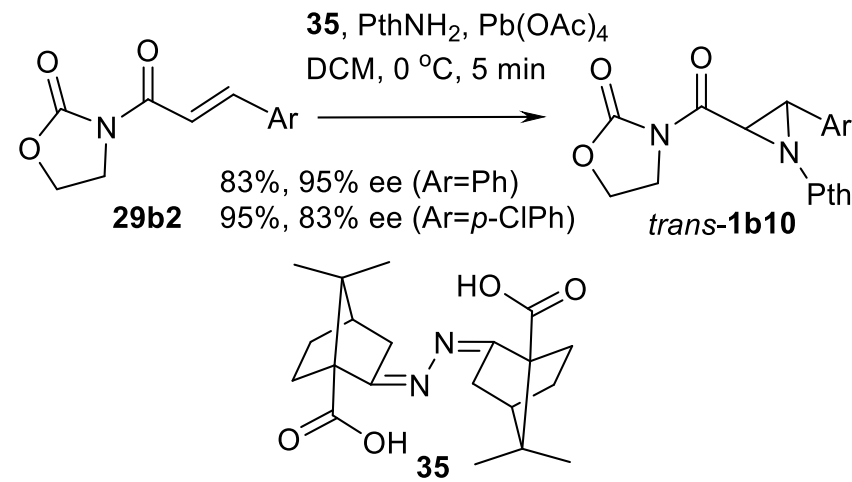

Scheme 30. Oxidative aziridination using a chiral ligand [106].

Similar $\mathrm{Pb}(\mathrm{OAc})_{4}$-mediated aziridination with $\mathrm{PthNH}_{2}$ as nitrogen source using chalcone and cinnamate type substrates was successfully employed to obtain aziridine intermediates for oxazole synthesis [107,108], spiro-fused N-phthalimidoaziridines [109] and 3(2-allylphenyl)aziridine-2-carboxylates [110] to investigate their thermal transformations.

Other oxidant systems used in this type of alkene aziridination include iodobenzene diacetate [111] and aril iodide- $m$-CPBA system [112]. Iodobenzene diacetate works well as oxidant in the aziridination of chalcones $29 \mathrm{c}$ and cinnamate $29 \mathrm{a}$ with $\mathrm{N}$-aminophtalimide ( $\mathrm{PthNH} \mathrm{N}_{2}$ ) or 3-amine-3H-benzoxazol-2-one $\left(\mathrm{BoNH}_{2}\right)$ as nitrogen sources. Yields of aziridines trans-1a,b (Scheme 31) are excellent [111].

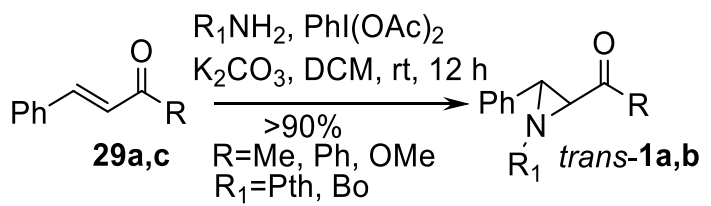

Scheme 31. Iodobenzene diacetate-promoted oxidative aziridination [111].

The same transformation using in situ generated oxidant made from $m$-CPBA and 4-methoxyphenyl iodide was demonstrated [112] and compared with $\mathrm{PhI}(\mathrm{OAc})_{2}$ oxidant in series of alkene substrates including chalcone 29c. The yields were comparable. Interesting utilization of $\mathrm{PthNH}_{2}-\mathrm{PhI}(\mathrm{OAc})_{2}$ aziridination was demonstrated by Yudin's group [113]; this system allowed them to obtain 3-phenyl-2-bromoaziridinylketones cis-1c7 from corresponding $\alpha$-bromoketones 29c1 in good yields (Scheme 32).

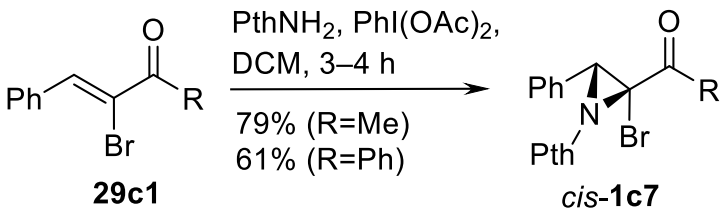

Scheme 32. Yudin's modification of oxidative aziridination [113].

Aziridination of highly functionalized chalcone and cinnamate type substrates with a $\mathrm{PthNH}_{2}$ nitrogen source and a $\mathrm{PhI}(\mathrm{OAc})_{2}$ oxidant was utilized for functionalized 3benzazepine skeleton construction [114] and for obtaining of fluorinated aziridines including 3- $\mathrm{C}_{6} \mathrm{~F}_{5}$ substituted aziridine-2-carboxylate 1a [115]. Example of highly functionalized biaryl aziridinyl ketone 1c8 (Scheme 33) synthesis from corresponding alkene via the $\mathrm{PthNH}_{2} / \mathrm{PhI}(\mathrm{OAc})_{2}$ system has been demonstrated [116]. 
<smiles>O=C(c1ccccc1-c1ccccn1)C1(c2ccccc2)[C@@H]2c3ccccc3[C@@H]21</smiles>

Scheme 33. An example of a highly functionalized product of oxidative aziridination [116].

An interesting and perspective oxidant in oxidative aziridination is sodium 2-iodoxybenzoate 36 generated from $o$-iodoxybenzoic acid (IBX) and $\mathrm{Na}_{2} \mathrm{CO}_{3}$ (Scheme 34) [117]. Various type 29 substrates including unsaturated ketones $29 \mathrm{c}$ and amides $29 \mathrm{~b}$ has been successfully aziridinated to obtain trans-1b, c type products in $65-92 \%$ yields (five examples).
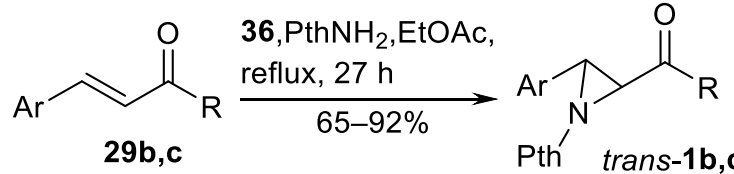

$\mathrm{Ar}=\mathrm{Ph}, 4-\mathrm{MeOPh}$

$\mathrm{R}=\mathrm{Me}, \mathrm{Ar}, \mathrm{CH}=\mathrm{CHPh}, \mathrm{NR}_{2} \quad \mathrm{Na}_{2} \mathrm{CO}_{3}$

\section{IBX}<smiles>O=C1OI(=O)([N+](=O)[O-])c2ccccc21</smiles>

Scheme 34. Sodium 2-iodoxybenzoate-promoted oxidative aziridination [117].

Another nitrogen source for substrate-controlled diastereoselective aziridination is 3-acetoxyaminoquinazolone (QNHOAc) in the presence of hexamethyldisilazane (HMDS) as shown in the Scheme 35 [118].

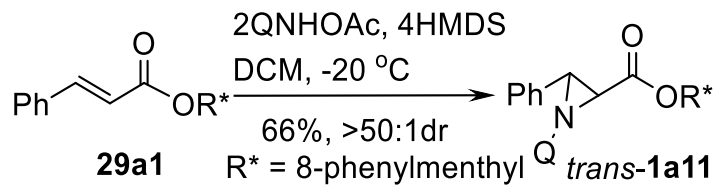

Scheme 35. QNOAc-promoted aziridination [118].

Aziridine ester trans-1a11 was obtained in good yield and diastereomeric excess from cinnamate 29a1. Intramolecular variation of this process also has been reported in the synthesis of the complex aziridine ester 1a12 depicted in the Scheme 36 [119].

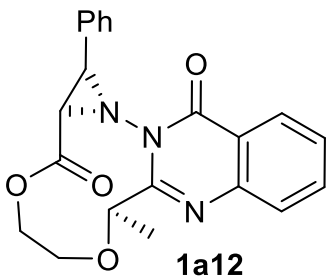

Scheme 36. The product of intramolecular aziridination [119].

An interesting nitrogen source (N-amino-endo-bicyclo[2.2.1]hept-5-ene-2.3-dicarboxylic acid diimide $37\left(\mathrm{EnH}-\mathrm{NH}_{2}\right)$ ) was investigated (Scheme 37$)$ in four examples, leading to the yields of $30-70 \%$ [120]. 


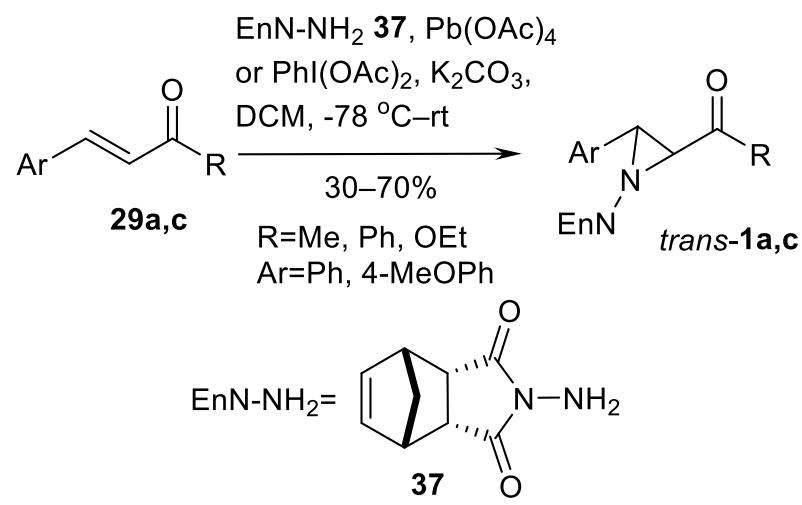

Scheme 37. EnH-NH 2 -promoted oxidative aziridination [120].

1-aminopyridinium iodide (Scheme 38) represented another original nitrogen source [121].

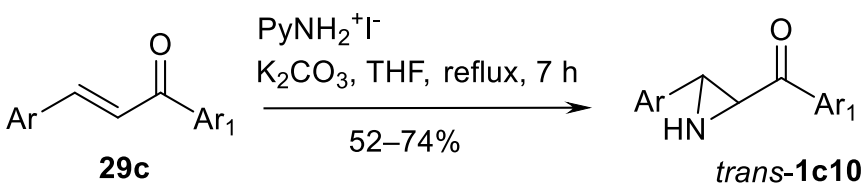

Scheme 38. 1-Aminopyridinium iodide as the nitrogen source in aziridination [121].

This NH-transferring agent allows to obtain NH aziridinylketones trans-1c10 from chalcones 29c in 52-74\% yield (11 examples) in a stereoselective one-pot process.

An example of substituted anilines 38 as nitrogen sources in oxidative aziridination of benzilidene dicarbonyl substrate $29 \mathrm{a} 2$ to obtain potential antibacterial aziridines $1 \mathrm{a} 12$ (Scheme 39) has been reported [122]. Aziridination was carried out at room temperature, and the yields of aziridines 1 a12 were good (60-70\%) in 15 examples.

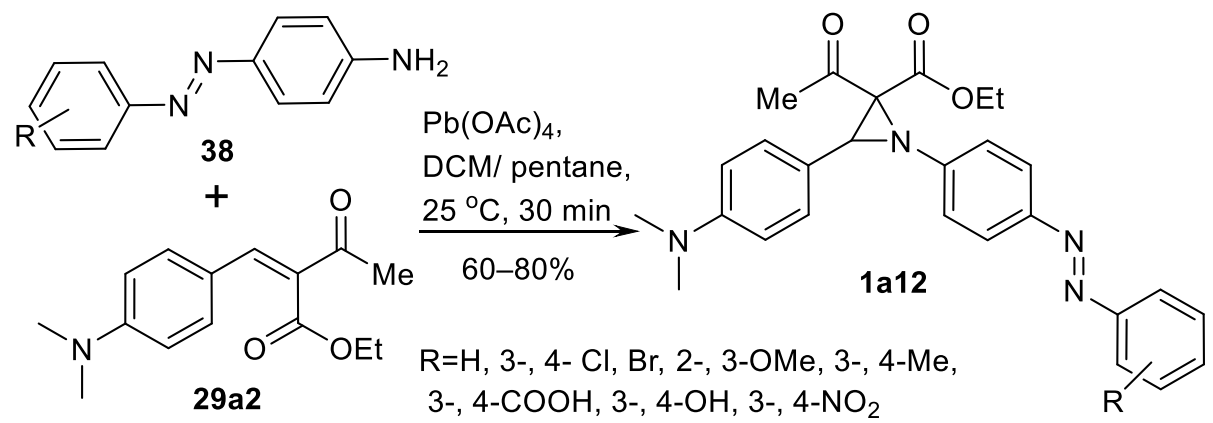

Scheme 39. Anilines as the nitrogen source in oxidative aziridination [122].

Lead or hypervalent iodine oxidants in oxidative aziridination with $\mathrm{PthNH}_{2}$ as a nitrogen source can be replaced with direct electrochemical oxidation via $+1.80 \mathrm{~V}$ potential [123]. Methyl cinnamate 29a and chalcone 29c have been aziridinated in yields of type trans-1a,c aziridines $86 \%$ and $83 \%$, respectively.

Oxaziridine 39 can be used simultaneously as oxidant and nitrogen source for oxidative nitrogen transfer alkene aziridinations in synthesis of 3-arylaziridine-2-carboxylates 1a1, and diesters $\mathbf{1 a 8}$ as shown in the Scheme 40 [124]. The reaction was carried out under mild conditions in presence of $\mathrm{MgI}_{2}$. 


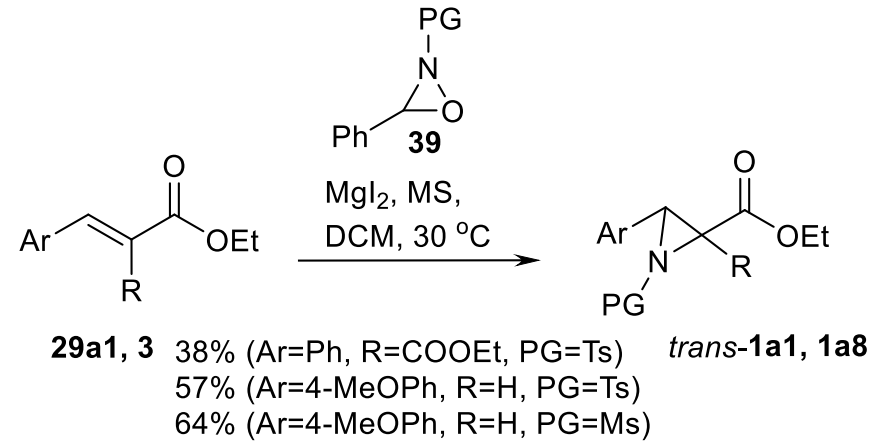

Scheme 40. Oxaziridine-promoted oxidative aziridination [124].

$\mathrm{N}, \mathrm{N}$-dihalogene-p-toluenesulfonamides are reported as nitrogen sources for both catalytic $[125,126]$ and non-catalytic [127] aziridinations of cinnamates, cinnamyl amides and chalcone type substrates $\mathbf{2 9 a}, \mathbf{c}, \mathbf{d}$ (Scheme 41). Interestingly, aziridination with $\mathrm{TsNCl}_{2}$ was demonstrated as a two-step addition-cyclization process $[125,126]$ via isolable intermediate 40, but the reaction with $\mathrm{TsNBr}_{2}$ was reported in a one-step nitrene transfer process [127]. The specific use of similar aziridinating agent $\mathrm{PhSO}_{2} \mathrm{NBr}_{2}$ under $\mathrm{Lu}(\mathrm{OTf})_{3} /$ chiral ligand catalysis for complex tricyclic aziridine synthesis was noted [128].

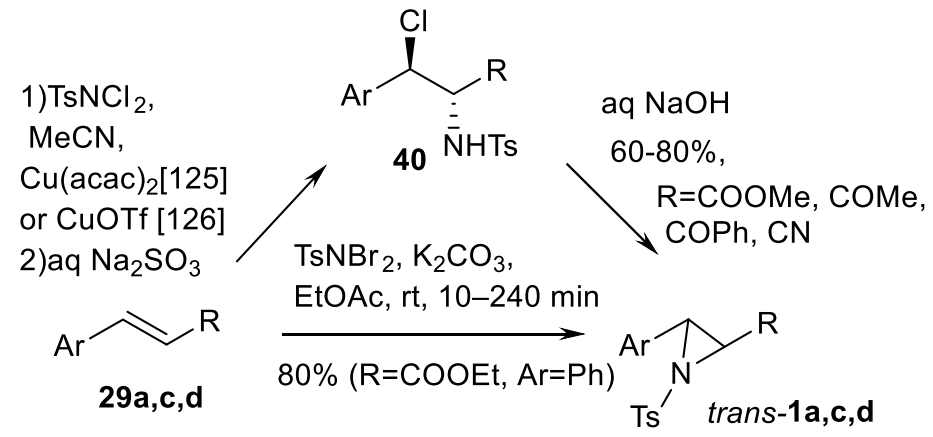

Scheme 41. N,N-dihalogene- $p$-toluenesulfonamides as the nitrogen source in aziridination [125-127].

The other nitrene sources are sulfenyl nitrenes generated from $\mathrm{N}$-sulfenylsulfodiimides [129] and bromamine $\mathrm{T}$ [130]. Sulfenyl nitrenes allow to obtain $\mathrm{N}$-sulfenylaziridines, a single example of N-sulfenylaziridine $\mathbf{1} \mathbf{1 1 1}$ has been demonstrated (60\% yield from chalcone [129]) (Scheme 42).<smiles></smiles>

Scheme 42. An example of N-sulfenylaziridine product [129].

Bromamine $\mathrm{T}$ is moderately effective as nitrene source for cinnamate substrates $29 \mathrm{a}$ (Scheme 41) under ultrasound conditions in the presence of $\mathrm{CuCl}_{2}$ forming aziridine-2carboxlates trans-1a (30-34\% yield) and under microwave in the presence of $\mathrm{CuBr}_{2}$ forming esters cis+trans-1a (Scheme 41) at 36-38\% yield [130].

\subsection{Hydroxylamines as Nitrogen Sources}

Classically, aziridines can be synthesized from conjugated $\alpha, \beta$-unsaturated substrates by the Michael-type addition followed by aziridine ring closure, usually under basic conditions. Thus, chalcone type substrates 29c (Scheme 43) undergo Michael addition of O-methylhydroxylamine under scandium (R)-1.1-binaphtyl-2.2'-diyl phosphate (BNP) complex catalysis and then perform cyclization of intermediate 41 into aziridines trans-1c 
under lanthanum (3) isopropoxide catalysis as shown in the Scheme 43 [131]. Remarkably, this is a route to 3-arylated NH-aziridin-2-ylketones trans-1c10. In case of racemic intermediate 41, a kinetic resolution using $\mathrm{La}(\mathrm{O} i-\mathrm{Pr})_{3}$-mediated cyclization into aziridine trans-1c10 in the presence of $(R)$ or $(S)$-BINOL is possible.

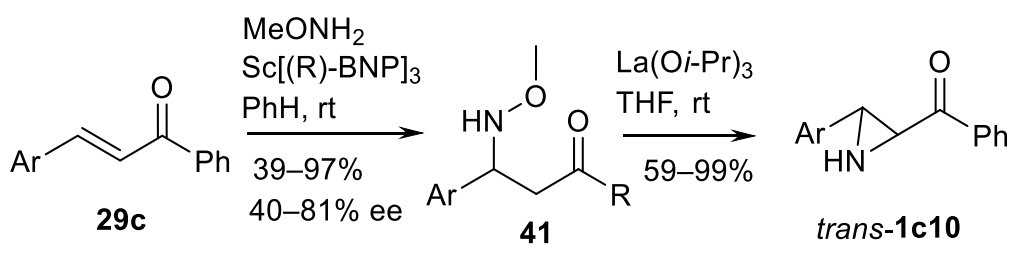

Scheme 43. Michael-type addition-based aziridination [131].

Highly functionalized aziridine ester 1 1a13 (yield 58\%) [132] and lactone 1a14 (yield $60 \%$ ) [133] can be produced from corresponding $\alpha, \beta$-unsaturated 29a type carboxylic ester and lactone, respectively, in reaction with carbamate reagent NsONHCOOEt in the presence of $\mathrm{CaO}$ (Scheme 44).<smiles>CCOC(=O)C1(CI)C2NC(=O)OCC21c1ccccc1</smiles>

$1 \mathrm{a} 13$<smiles></smiles>

$1 \mathrm{a} 14$

Scheme 44. Carbamate reagent-based aziridination products [132,133].

Similar asymmetric organocatalytic aziridination of enones with carbamate reagent TsONHCbz in the presence of catalyst salt $\mathbf{4 2}$ (Scheme 45) has been reported [134]. Aziridinyl ketones trans-1c12 were obtained in good yields and ee.<smiles>CC(=O)/C=C/Br</smiles>

TsONHCbz,

$42(20 \mathrm{~mol} \%)$,

$2 \mathrm{NaHCO}_{3}$,<smiles>CCC1C[C@@H]2CC[C@H]1N2C[C@H](N)c1ccnc2ccc(OC)cc12</smiles>

$\mathrm{CHCl}_{3}, 23{ }^{\circ} \mathrm{C}$<smiles>CC(=O)C1C([AlH2])N1[14C](=O)[O-]</smiles>

$85 \%(73 \%$ ee $), \mathrm{Ar}=\mathrm{Ph}$<smiles>CCCCCCCC(=O)C(C(=O)[O-])c1ccccc1</smiles>

trans-1c12 92\% (99\% ee), $\mathrm{Ar}=p-\mathrm{NO}_{2} \mathrm{Ph}$

Scheme 45. Asymmetric organocatalytic aziridination of enones with carbamate reagent [134].

In the same way, employing TsONHBoc reagent and chiral diphenylprolinol triethylsilyl ether $\mathbf{4 3}$ organocatalyst, enantioselective organocatalytic aziridination of $\alpha, \beta-$ unsaturated aldehydes 29d (Scheme 46) can be performed [135]. 


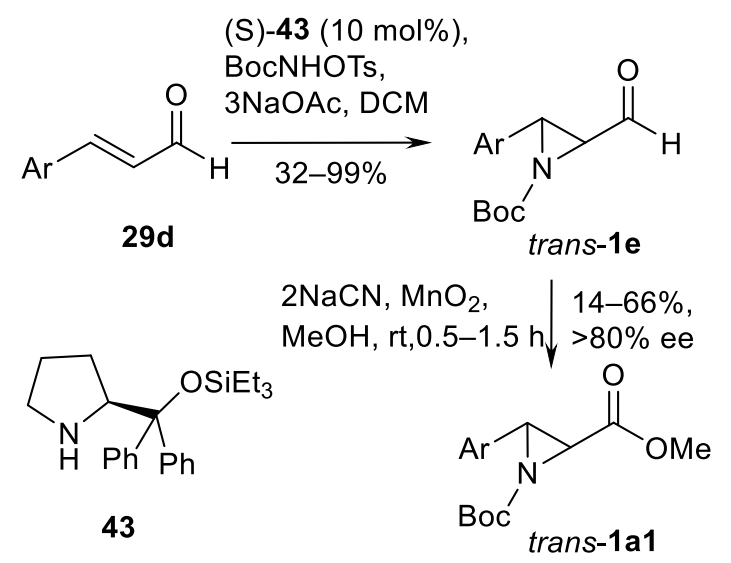

Scheme 46. Enantioselective organocatalytic aziridination of $\alpha, \beta$-unsaturated aldehydes [135].

Synthesis of various 3-arylated aziridine aldehydes trans-1e and corresponding esters trans-1a1 (Scheme 46) has been demonstrated in 18 examples showing good yields and enantioselectivity $(>80 \%$ ee). Aryl substituents include various substituted phenyls, fluorinated phenyls and 3-piridyls. Enantioselective synthesis of $(R)$-sumanirole employing this aldehyde 29d aziridination method was reported [136]. The syntheses of spiroaziridine oxindoles 1 b8 (13 examples, 74-98\% yields) are performed using BocONHCbz hydroxylamine in the presence of tetramethylguanidine [137]. An isolated example of inactivated aziridin-2-ylketone trans-1c13 (Scheme 47) (60\% yield) in TsONHMe-mediated aziridination under $\mathrm{Rh}_{2}(\mathrm{esp})_{2}$ catalysis (Scheme 47) was demonstrated [138].

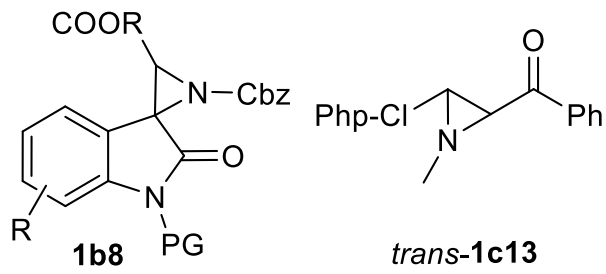

$\mathrm{R}=\mathrm{Me}, \mathrm{Et}, t-\mathrm{Bu}, 4-\mathrm{Br}, 5-\mathrm{Br}, 6-\mathrm{Br}, 4-\mathrm{Cl}, 5-\mathrm{Cl}, 2-\mathrm{F}$ $\mathrm{PG}=\mathrm{Me}, \mathrm{Bn}$

Scheme 47. Hydroxylamine reagent-mediated aziridination products [137,138].

Finally, Armstrong's aziridination must be noted as a remarkable advance in the direct access to 3-arylated N-unsubstituted aziridin-2-yl ketones trans-1c10 (Scheme 48) and carboxylates trans-1a15. Armstrong's aziridination implies the use of $\mathrm{N}, \mathrm{N}-y$ lides generated from N-methylmorpholine, or other tertiary amines in the presence of $\mathrm{Ph}_{2} \mathrm{P}(\mathrm{O}) \mathrm{ONH}_{2}$ $\left(\mathrm{dppONH}{ }_{2}\right)$ as $\mathrm{NH}$ transfer agent (Scheme 48) [139-141].

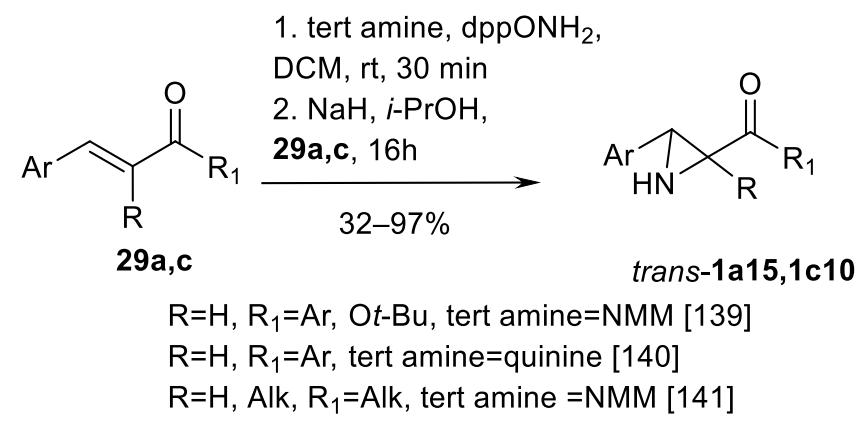

Scheme 48. Armstrong's aziridination [139-141].

In the initial work [139], chalcones and cinnamates 29a, c were successfully aziridinated to obtain trans-aziridine-2-ketones 1c10 and carboxylates trans-1a15 (Scheme 48) 
using N-methylmorpholine. The yields were 32-97\%; higher yields were obtained by chalcones $29 \mathrm{c}$. Enantioselective variation of this process using quinine as tertiary amine (yields $35-68 \%$ and $37-56 \%$ ee, eight examples) [140] and aziridination of highly functionalized alkyl arylidene ketones 29c (Scheme 48) (yields 51-81\%) has been reported [141].

\section{Conclusions}

Aziridination has a great synthetic potential in synthesis of 3-arylated aziridine-2carboxylates, carboxamides and 2-aziridinylketones. The most important, well-explored, and practical in terms of imine $\mathrm{C}=\mathrm{N}$ bond aziridination are Wulff's catalytic $\mathrm{AZ}$ reaction employing diazo compounds as carbene sources and various catalytic systems.

This method demonstrates a high stereoselectivity in a broad series of examples and allow obtaining both cis and trans aziridine products including nitriles and aldehydes selectively. In $\mathrm{C}=\mathrm{C}$ bond aziridination, the main approaches include Evans olefin aziridination using $\mathrm{PhI}=\mathrm{NTs}$ type nitrene sources under $\mathrm{Cu}$ catalysis, as well as oxidative aziridination variations.

Notably, Evans aziridination is suitable for aziridination of chalcone and cinnamate type substrates and oxidative methods allows to obtain also 3-arylaziridine-2-carboxamides. Remarkable are several methods which allow to directly access $\mathrm{NH}$ aziridines, such as Armstrong's aziridination.

Author Contributions: Conceptualization, B.S.; methodology and validation, B.S. and I.S.; investigation, B.S., R.U. and K.V.; resources, P.T.; writing—original draft preparation, B.S., R.U. and K.V.; writing-review and editing, B.S. and I.S.; visualization, B.S.; supervision, B.S. and I.S.; funding acquisition, P.T. All authors have read and agreed to the published version of the manuscript.

Funding: This research was funded by European Regional Development Fund; project number No. 1.1.1.2/VIAA/1/16/242. The APC was funded by Riga Stradins university, Riga, Latvia.

Institutional Review Board Statement: Not applicable.

Informed Consent Statement: Not applicable.

Acknowledgments: Authors are grateful to European Regional Development Fund for the financial support via project No. 1.1.1.2/VIAA/1/16/242 and to State Education Development Agency of Latvia for excellent administrative support.

Conflicts of Interest: The authors declare no conflict of interest.

\section{References}

1. Tanner, D. Chiral Aziridines-Their Synthesis and Use in Stereoselective Transformations. Angew. Chem. Int. Ed. 1994, 33, 599-619. [CrossRef]

2. Iynegar, B.S.; Dorr, R.T.; Remers, W.A. Chemical basis for the biological activity of imexon and related cyanoaziridines. J. Med. Chem. 2004, 47, 218-223. [CrossRef]

3. Kalvinsh, I.Y.; Astapenok, E.B. Pharmaceutical Composition and Method for Treating Tumors Susceptible to 2-Carbamoylaziridine. U.S. Patent 4686215; Application US 06/693,171, 11 August 1987.

4. Rajendra Prasad, N.; Karthikeyan, A.; Karthikeyan, S.; Reddy, B.V. Inhibitory effect of caffeic acid on cancer cell proliferation by oxidative mechanism in human HT-1080 fibrosarcoma cell line. Mol. Cell Biochem. 2011, 349, 11-19. [CrossRef] [PubMed]

5. Chen, Y.-C.; Kuo, Y.-H.; Yang, N.-C.; Liu, C.-W.; Chang, W.-T.; Hsu, C.-L.J. Cytotoxic and apoptotic effects of caffeate derivatives on A549 human lung carcinoma cells. Chin. Med. Assoc. 2014, 77, 535-543. [CrossRef] [PubMed]

6. Kong, C.-S.; Jeong, C.-H.; Choi, J.-S.; Kim, K.-J.; Jeong, J.-W. Antiangiogenic effects of p-coumaric acid in human endothelial cells. Phytother. Res. 2013, 27, 317-323. [CrossRef] [PubMed]

7. Ivanova, J.; Žalubovskis, R. Derivatives of 2-Aziridinyl Ketones and Aziridinyl-2-Carboxylates. Chem. Heterocycl. Compd. 2016, 52, 535-537. [CrossRef]

8. Singh, G.S. Advances in synthesis and chemistry of aziridines. Adv. Heterocycl. Chem. 2019, 129, 246-335. [CrossRef]

9. Degennaro, L.; Trinchera, P.; Luisi, R. Recent Advances in the Stereoselective Synthesis of Aziridines. Chem. Rev. 2014, 114, 7881-7929. [CrossRef] [PubMed]

10. Antilla, J.C.; Wulff, W.D. Catalytic Asymmetric Aziridination with Arylborate Catalysts Derived from VAPOL and VANOL Ligands. Angew. Chem. Int. Ed. 2000, 39, 4518-4521. [CrossRef]

11. Loncaric, C.; Wulff, W.D. An Efficient Synthesis of (-)-Chloramphenicol via Asymmetric Catalytic Aziridination: A Comparison of Catalysts Prepared from Triphenylborate and Various Linear and Vaulted Biaryls. Org. Lett. 2001, 3, 3675-3678. [CrossRef] 
12. Wang, Z.; Li, F.; Zhao, L.; He, Q.; Chen, F.; Zheng, C. An efficient enantioselective synthesis of florfenicol via asymmetric aziridination. Tetrahedron 2011, 67, 9199-9203. [CrossRef]

13. Lu, Z.; Zhang, Y.; Wulff, W.D.J. Direct Access to N-H-Aziridines from Asymmetric Catalytic Aziridination with Borate Catalysts Derived from Vaulted Binaphthol and Vaulted Biphenanthrol Ligands. Am. Chem. Soc. 2007, 129, 7185-7194. [CrossRef] [PubMed]

14. Deng, Y.; Lee, Y.R.; Newman, C.A.; Wulff, W.D. Aziridinyl Vinyl Ketones from the Asymmetric Catalytic Aziridination Reaction. Eur. J. Org. Chem. 2007, 2068-2071. [CrossRef]

15. Zhang, Y.; Desai, A.A.; Lu, Z.; Hu, G.; Ding, Z.; Wulff, W.D. Catalytic Asymmetric Aziridination with Borate Catalysts Derived from VANOL and VAPOL Ligands: Scope and Mechanistic Studies. Chem. Eur. J. 2008, 14, 3785-3803. [CrossRef]

16. Zhang, Y.; Lu, Z.; Desai, A.; Wulff, W.D. Mapping the Active Site in a Chemzyme: Diversity in the N-Substituent in the Catalytic Asymmetric Aziridination of Imines. Org. Lett. 2008, 10, 5429-5432. [CrossRef]

17. Hu, G.; Huang, L.; Huang, R.H.; Wulff, W.D. Evidence for a Boroxinate Based Brønsted Acid Derivative of VAPOL as the Active Catalyst in the Catalytic Asymmetric Aziridination Reaction. J. Am. Chem. Soc. 2009, 131, 15615-15617. [CrossRef] [PubMed]

18. Desai, A.A.; Wulff, W.D. Controlled Diastereo- and Enantioselection in a Catalytic Asymmetric Aziridination. J. Am. Chem. Soc. 2010, 132, 13100-13103. [CrossRef]

19. Vetticatt, M.J.; Desai, A.A.; Wulff, W.D. How the Binding of Substrates to a Chiral Polyborate Counterion Governs Diastereoselection in an Aziridination Reaction: H-Bonds in Equipoise. J. Am. Chem. Soc. 2010, 132, 13104-13107. [CrossRef] [PubMed]

20. Ren, H.; Wulff, W.D. Trimethylsilyldiazomethane as a Versatile Stitching Agent for the Introduction of Aziridines into Functionalized Organic Molecules. Org. Lett. 2010, 12, 4908-4911. [CrossRef]

21. Mukherjee, M.; Gupta, A.K.; Lu, Z.; Zhang, Y.; Wulff, W.D. Seeking Passe-Partout in the Catalytic Asymmetric Aziridination of Imines: Evolving Toward Substrate Generality for a Single Chemzyme. J. Org. Chem. 2010, 75, 5643-5660. [CrossRef]

22. Hu, G.; Gupta, A.K.; Huang, R.H.; Mukherjee, M.; Wulff, W.D. Substrate-Induced Covalent Assembly of a Chemzyme and Crystallographic Characterization of a Chemzyme-Substrate Complex. J. Am. Chem. Soc. 2010, 132, 14669-14675. [CrossRef]

23. Huang, L.; Wulff, W.D. Catalytic Asymmetric Synthesis of Trisubstituted Aziridines. J. Am. Chem. Soc. 2011, 133, 8892-8895. [CrossRef]

24. Desai, A.A.; Ren, H.; Mukherjee, M.; Wulff, W.D. Practical Gram Scale Asymmetric Catalysis with Boroxinate Brønsted Acids Derived from the VAPOL and VANOL Ligands. Org. Process Res. Dev. 2011, 15, 1108-1115. [CrossRef]

25. Huang, L.; Zhang, Y.; Staples, R.J.; Huang, R.H.; Wulff, W.D. Double Stereodifferentiation in the Catalytic Asymmetric Aziridination of Imines Prepared from $\alpha$-Chiral Amines. Chem. Eur. J. 2012, 18, 5302-5313. [CrossRef]

26. Gupta, A.K.; Mukherjee, M.; Hu, G.; Wulff, W.D. BOROX Catalysis: Self-assembled amino-BOROX and imino-BOROX Chiral Brønsted Acids in a Five Component Catalyst Assembly/Catalytic Asymmetric Aziridination. J. Org. Chem. 2012, 77, 7932-7944. [CrossRef]

27. Guan, Y.; Ding, Z.; Wulff, W.D. Vaulted Biaryls in Catalysis: A Structure-Activity Relationship Guided Tour of the Immanent Domain of the VANOL Ligand. Chem. Eur. J. 2013, 19, 15565-15571. [CrossRef] [PubMed]

28. Gupta, A.K.; Zhang, X.; Staples, R.J.; Wulff, W.D. The iso-VAPOL ligand: Synthesis, solid-state structure and its evaluation as a BOROX catalyst. Catal. Sci. Tecnol. 2014, 4, 4406-4415. [CrossRef]

29. Hu, G.; Gupta, A.K.; Huang, L.; Zhao, W.; Yin, X.; Osminski, W.E.G.; Huang, R.H.; Wulff, W.D.; Izzo, J.A.; Vetticatt, M.J. Pyro-Borates, Spiro-Borates, and Boroxinates of BINOL-Assembly, Structures, and Reactivity. J. Am. Chem. Soc. 2017, 139, 10267-10285. [CrossRef] [PubMed]

30. Bew, S.P.; Liddle, J.; Hughes, D.L.; Pesce, P.; Thurston, S.M. Chiral Brønsted Acid-Catalyzed Asymmetric Synthesis of N-Aryl-cisaziridine Carboxylate Esters. Angew. Chem. Int. Ed. 2017, 56, 5322-5326. [CrossRef]

31. Gupta, A.K.; Mukherjee, M.; Wulff, W.D. Multicomponent catalytic asymmetric aziridination of aldehydes. Org. Lett. 2011, 13, 5866-5869. [CrossRef] [PubMed]

32. Zhou, Y.; Gupta, A.K.; Mukherjee, M.; Zheng, L.; Wulff, W.D. Multicomponent Catalytic Asymmetric Aziridination of Aldehydes. J. Org. Chem. 2017, 82, 13121-13140. [CrossRef] [PubMed]

33. Hashimoto, T.; Galvez, A.O.; Maruoka, K. In Situ Assembled Boronate Ester Assisted Chiral Carboxylic Acid Catalyzed Asymmetric Trans-Aziridinations. J. Am. Chem. Soc. 2013, 135, 17667-17670. [CrossRef] [PubMed]

34. Hashimoto, T.; Nakatsu, H.; Yamamoto, K.; Maruoka, K. Chiral Brønsted Acid-Catalyzed Asymmetric Trisubstituted Aziridine Synthesis Using $\alpha$-Diazoacyl Oxazolidinones. J. Am. Chem. Soc. 2011, 133, 9730-9733. [CrossRef]

35. Zeng, X.; Zeng, X.; Xu, Z.; Lu, M.; Zhong, G. Highly Efficient Asymmetric Trans-Selective Aziridination of Diazoacetamides and N-Boc-imines Catalyzed by Chiral Brønsted Acids. Org. Lett. 2009, 11, 3036-3039. [CrossRef]

36. Hashimoto, T.; Uchiyama, N.; Maruoka, K. Trans-Selective Asymmetric Aziridination of Diazoacetamides and N-Boc Imines Catalyzed by Axially Chiral Dicarboxylic Acid. J. Am. Chem. Soc. 2008, 130, 14380-14381. [CrossRef]

37. Ranocchiari, M.; Mezzeti, A. Ru/PNNP-Catalyzed Asymmetric Imine Aziridination by Diazo Ester Activation. Organometallics 2009, 28, 3611-3613. [CrossRef]

38. Egloff, J.; Ranocchiari, M.; Schira, A.; Schotes, C.; Mezzeti, A. Highly Enantioselective Ruthenium/PNNP-Catalyzed Imine Aziridination: Evidence of Carbene Transfer from a Diazoester Complex. Organometallics 2013, 32, 4690-4701. [CrossRef]

39. Li, Y.; Chan, W.H.; Zhu, N.-Y.; Che, C.-M.; Kwong, H.-L. Ruthenium(II) Porphyrin Catalyzed Imine Aziridination and Crystal Structures of (meso-Tetrakis(pentafluorophenyl)porphyrinato)ruthenium(II) Complexes Containing $\mathrm{PhNCH}(\mathrm{p}-\mathrm{ClPh}), \mathrm{CPh} 2$, and Pyridine Ligands. Organometallics 2004, 23, 54-66. [CrossRef] 
40. Redlich, M.; Hossain, M.M. Synthesis of asymmetric iron-pybox complexes and their application to aziridine forming reactions. Tetrahedron Lett. 2004, 45, 8987-8990. [CrossRef]

41. Krumper, J.R.; Gerisch, M.; Suh, J.M.; Bergman, R.G.; Tilley, T.D. Monomeric Rhodium(II) Catalysts for the Preparation of Aziridines and Enantioselective Formation of Cyclopropanes from Ethyl Diazoacetate at Room Temperature. J. Org. Chem. 2003, 68, 9705-9710. [CrossRef] [PubMed]

42. Hashimoto, T.; Nakatsu, H.; Watanabe, S.; Maruoka, K. Stereoselective Synthesis of Trisubstituted Aziridines with N- $\alpha$-Diazoacyl Camphorsultam. Org. Lett. 2010, 12, 1668-1671. [CrossRef] [PubMed]

43. Hashimoto, T.; Nakatsu, H.; Yamamoto, K.; Watanabe, S.; Maruoka, K. Asymmetric Trisubstituted Aziridination of Aldimines and Ketimines using N- $\alpha$-Diazoacyl Camphorsultams. Chem. Asian J. 2011, 6, 607-613. [CrossRef] [PubMed]

44. Zhang, X.-J.; Yan, M.; Huang, D. Catalyzed addition of diazoacetoacetates to imines: Synthesis of highly functionalized aziridines. Org. Biomol. Chem. 2009, 7, 187-192. [CrossRef] [PubMed]

45. Sun, W.; Xia, C.G.; Wang, H.-W. Synthesis of aziridines from imines and ethyl diazoacetate in room temperature ionic liquids. Tetrahedron Lett. 2003, 44, 2409-2411. [CrossRef]

46. Yadav, J.S.; Reddy, B.V.S.; Rao, M.S. Bi(OTf)3-[Bmim]PF6: A novel and Reusable Catalytic System for the Synthesis of cis -Aziridine Carboxylates. Synthesis 2003, 9, 1387-1390. [CrossRef]

47. Mazumdar, A.; Xue, Z.; Mayer, M.F. A Catalytic Synthesis of Aziridines without the Usual Byproducts. Synlett 2007, 13, 2025-2028. [CrossRef]

48. Zhao, Y.; Wang, G.; Zhou, S.; Liz, Z.; Meng, X. Diastereoselective formation of aziridines from diazocarbonyl compounds and $\mathrm{N}-(\mathrm{O}-$ pivaloylated D-galactosyl)benzylideneamines and ring-opening reactions with p-toluenethiol. Org. Biomol. Chem. 2014, 12, 3362-3365. [CrossRef] [PubMed]

49. Borkin, D.; Carlson, A.; Török, B. K-10-Catalyzed Highly Diastereoselective Synthesis of Aziridines. Synlett 2010, 5, 745-748. [CrossRef]

50. Yadav, J.S.; Reddy, B.V.S.; Rao, M.S.; Reddy, P.N. $\mathrm{LiClO}_{4}$-catalyzed highly diastereoselective synthesis of cis-aziridine carboxylates. Tetrahedron Lett. 2003, 44,5275-5278. [CrossRef]

51. Doyle, M.P.; Hu, W.; Timmons, J.D. Epoxides and Aziridines from Diazoacetates via Ylide Intermediates. Org. Lett. 2001, 3 , 933-935. [CrossRef]

52. Hue, Z.; Mazumdar, A.; Hope-Weeks, L.J.; Mayer, M.F. Aziridine synthesis in the presence of catalytic amounts of pyridiniums or viologens. Tetrahedron Lett. 2008, 49, 4601-4603. [CrossRef]

53. Bew, S.P.; Carrington, R.; Hughes, D.L.; Liddle, J.; Pesce, P. An Organocatalytic Synthesis of cis-N-Alkyl- and N-Arylaziridine Carboxylates. Adv. Synth. Catal. 2009, 351, 2579-2588. [CrossRef]

54. Bew, S.P.; Fairhurst, S.A.; Hughes, D.L.; Legentil, L.; Liddle, J.; Pesce, P.; Nigudkar, S.; Wilson, M.A. Organocatalytic Aziridine Synthesis Using F+ Salts. Org. Lett. 2009, 11, 4552-4555. [CrossRef] [PubMed]

55. Huo, C.; Sun, C.; Hu, D.; Jia, X.; Xu, X.; Liu, Z. Cation radical induced cycloaddition reaction between aryl imines and ethyl diazoacetate. Tetrahedron Lett. 2011, 52, 7008-7010. [CrossRef]

56. Bew, S.P.; Coles, S.J.; Pitak, M.B.; Klooster, W.T.; Ashford, P.-A.; Zdorichenko, V. Generating cis-aza-diaryl and triaryl ethers via organoBrønsted acid catalysed aza-Darzens chemistry. Tetrahedron 2019, 75, 130532-130539. [CrossRef]

57. Lee, K.-D.; Suh, J.-M.; Park, J.H.; Ha, H.-J.; Choi, H.G.; Park, C.S.; Chang, J.W.; Lee, W.K.; Dong, Y.; Yun, H. New synthesis and ring opening of cis-3-alkylaziridine-2-carboxylates. Tetrahedron 2001, 57, 8267-8276. [CrossRef]

58. Sweeney, J.B.; Cantrill, A.A.; McLaren, A.B.; Thobhani, S. Asymmetric aziridine synthesis by aza-Darzens reaction of Ndiphenylphosphinylimines with chiral enolates. Part 1: Formation of cis-aziridines. Tetrahedron 2006, 62, 3681-3693. [CrossRef]

59. Sweeney, J.B.; Cantrill, A.A.; Drew, M.G.B.; McLaren, A.B.; Thobhani, S. Asymmetric aziridine synthesis by aza-Darzens reaction of N-diphenylphosphinylimines with chiral enolates. Part 2: Inversion of diastereoselectivity. Tetrahedron 2006, 62, 3694-3703. [CrossRef]

60. Kattuboina, A.; Li, G. Chiral N-phosphonyl imine chemistry: New reagents and their applications for asymmetric reactions. Tetrahedron Lett. 2008, 49, 1573-1577. [CrossRef]

61. Kattamuri, P.V.; Xiong, Y.; Pan, Y.; Li, G. N,N-Diisopropyl-N-phosphonyl imines lead to efficient asymmetric synthesis of aziridine-2-carboxylic esters. Org. Biomol. Chem. 2013, 11, 3400-3408. [CrossRef]

62. Moragas Solà, T.; Churcher, I.; Lewis, W.; Stockman, R.A. Stereoselective aza-Darzens reactions of tert-butanesulfinimines: Convenient access to chiral aziridines. Org. Biomol. Chem. 2011, 9, 5034-5035. [CrossRef]

63. Roe, C.; Moragas Solà, T.; Sasraku-Neequaye, L.; Hobbs, H.; Churcer, I.; MacPherson, D.; Stockman, R.A. On the utility of S-mesitylsulfinimines for the stereoselective synthesis of chiral amines and aziridines. Chem. Commun. 2011, 47, 7491-7493. [CrossRef] [PubMed]

64. Moragas Solà, T.; Churcher, I.; Lewis, W.; Stockman, R.A. Asymmetric Synthesis of Trisubstituted Aziridines via Aza-Darzens Reaction of Chiral Sulfinimines. Org. Lett. 2014, 16, 6290-6293. [CrossRef] [PubMed]

65. Trost, B.M.; Saget, T.; Hung, C.-I. Efficient Access to Chiral Trisubstituted Aziridines via Catalytic Enantioselective Aza-Darzens Reactions. Angew. Chem. Int. Ed. 2017, 56, 2440-2444. [CrossRef] [PubMed]

66. Larson, S.E.; Li, G.; Rowland, G.B.; Junge, D.; Huang, R.; Lee Woodcock, H.; Antilla, J.C. Catalytic Asymmetric Aza-Darzens Reaction with a Vaulted Biphenanthrol Magnesium Phosphate Salt. Org. Lett. 2011, 13, 2188-2191. [CrossRef] [PubMed] 
67. Wu, X.; Li, L.; Zhang, J. Direct Aza-Darzens Aziridination of N-Tosylimines with 2-Bromomalonates for the Synthesis of Highly Functionalized Donor-Acceptor Aziridines. Adv. Synth. Catal. 2012, 354, 3485-3489. [CrossRef]

68. Fan, R.; Ye, Y. Iodobenzene Diacetate/Tetrabutylammonium Iodide-Induced Aziridination of N-Tosylimines with Activated Methylene Compounds under Mild Conditions. Adv. Synth. Catal. 2008, 350, 1526-1530. [CrossRef]

69. Fan, R.; Wang, L.; Ye, Y.; Zhang, J. Facile iodine(III)-induced oxidative cycloaddition of N-sulfonyl imines with methylene compounds under neutral conditions. Tetrahedron Lett. 2009, 50, 3857-3859. [CrossRef]

70. Tarui, A.; Kawashima, N.; Sato, K.; Omote, M.; Ando, A. Diastereoselective synthesis of 2-fluoroaziridine-2-carboxylates by Reformatsky-type aza-Darzens reaction. Tetrahedron Lett. 2010, 51, 4246-4249. [CrossRef]

71. Huang, Z.A.; Liu, H.; Lu, C.D.; Xu, Y.-J. An Approach to 3-(Indol-2-yl)succinimide Derivatives by Manganese-Catalyzed C-H Activation. Org. Lett. 2015, 17, 4042-4045. [CrossRef] [PubMed]

72. Hada, K.; Watanabe, T.; Isobe, T.; Ishikawa, T.J. Guanidinium Ylides as a New and Recyclable Source for Aziridines and Their Roles as Chiral Auxiliaries. Am. Chem. Soc. 2001, 123, 7705-7706. [CrossRef]

73. Haga, T.; Ishikawa, T. Mechanistic approaches to asymmetric synthesis of aziridines from guanidinium ylides and aryl aldehydes. Tetrahedron 2005, 61, 2857-2869. [CrossRef]

74. Kumamoto, T.; Nagayama, S.; Hayashi, Y.; Kojima, H.; David, L.; Nakanishi, W.; Ishikawa, T. Epimerization of trans-3Arylaziridine-2-carboxylates at the C3 Position. Heterocycles 2008, 76, 1155-1170. [CrossRef]

75. Takahashi, M.; Suzuki, N.; Ishikawa, T. Enantioselective Formal Synthesis of (-)-Podophyllotoxin from (2S,3R)-3-Arylaziridine-2carboxylate. J. Org. Chem. 2013, 78, 3250-3261. [CrossRef] [PubMed]

76. Khantikaew, I.; Takahashi, M.; Kumamoto, T.; Suzuki, N.; Ishikawa, T. Synthesis of (-)-benzolactam-V8 by application of asymmetric aziridination. Tetrahedron 2012, 68, 278-882. [CrossRef]

77. Oda, Y.; Hada, K.; Miyata, M.; Takahata, C.; Hayashi, Y.; Takahashi, M.; Yajima, N.; Fujinami, M.; Ishikawa, T. Guanidinium Ylide Mediated Aziridination from Arylaldehydes: Scope and Limitations in the Formation of Unactivated 3-Arylaziridine-2carboxylates. Synthesis 2014, 46, 2201-2219. [CrossRef]

78. Yadav, L.D.S.; Garima, R.K. Organocatalytic Stereoselective Aziridination of Imines via Ammonium Ylides. Synlett 2009, 19, 3123-3126. [CrossRef]

79. Aichhorn, S.; Gururaja, G.N.; Reisinger, M.; Waser, M. Scope and limitations of diastereoselective aziridination reactions using stabilised ammonium ylides or $\alpha$-bromo carbonyl nucleophiles. RSC Adv. 2013, 3, 4552-4557. [CrossRef]

80. Pichler, M.; Novacek, J.; Robiette, R.; Poscher, V.; Himmelsbach, M.; Monkowius, U.; Müller, N.; Waser, M. Asymmetric syntheses of three-membered heterocycles using chiral amide-based ammonium ylides. Org. Biomol. Chem. 2015, 13, 2092-2099. [CrossRef]

81. Aggarwal, V.K.; Ferara, M.; O’Brien, C.J.; Thompson, A.; Jones, R.V.H.; Fieldhouse, R. Scope and limitations in sulfur ylide mediated catalytic asymmetric aziridination of imines: Use of phenyldiazomethane, diazoesters and diazoacetamides. J. Chem. Soc. Perkin Trans. 2001, 14, 1635-1643. [CrossRef]

82. Aggarwal, V.K.; Charmant, J.P.H.; Ciampi, C.; Hornby, J.M.; O’Brien, C.J.; Hynd, G.; Parsons, R. Additions of stabilised and semi-stabilised sulfur ylides to tosyl protected imines: Are they under kinetic or thermodynamic control? J. Chem. Soc. Perkin Trans. 2001, 23, 3159-3166. [CrossRef]

83. Yang, X.-F.; Zhang, M.-J.; Hou, X.-L.; Dai, L.-X. Stereocontrolled Aziridination of Imines via a Sulfonium Ylide Route and a Mechanistic Study. J. Org. Chem. 2002, 67, 8097-8103. [CrossRef] [PubMed]

84. Hajra, S.; Aziz, S.M.; Jana, B.; Mahish, P.; Das, D. Synthesis of Chiral Spiro-Aziridine Oxindoles via Aza-Corey-Chaykovsky Reaction of Isatin Derived N-tert-Butanesulfinyl Ketimines. Org. Lett. 2016, 18, 532-535. [CrossRef] [PubMed]

85. Xu, Y.-N.; Tian, S.K. Facile construction of three-membered rings via benzyne-promoted Darzens-type reaction of tertiary amines. Tetrahedron 2019, 75, 1632-1638. [CrossRef]

86. Evans, D.A.; Faul, M.M.; Bilodeau, M.T. Copper-catalyzed aziridination of olefins by (N-(p-toluenesulfonyl)imino)phenyliodinane. J. Org. Chem. 1991, 56, 6744-6746. [CrossRef]

87. Evans, D.A.; Faul, M.M.; Bilodeau, M.T. Development of the Copper-Catalyzed Olefin Aziridination Reaction. J. Am. Chem. Soc. 1994, 116, 2742-2753. [CrossRef]

88. Södergren, M.J.; Alonso, D.A.; Andersson, P.G. Readily available nitrene precursors increase the scope of Evans' asymmetric aziridination of olefins. Tetrahedron Assymetry 1997, 8, 3563-3565. [CrossRef]

89. Dauban, P.; Sanière, L.; Tarrade, A.; Dod, R.H. Copper-Catalyzed Nitrogen Transfer Mediated by Iodosylbenzene PhI=O. J. Am. Chem. Soc. 2001, 123, 7707-7708. [CrossRef] [PubMed]

90. Shi, M.; Wang, C.-J. Axially dissymmetric (R)-(+)-5, $5^{\prime}, 6,6^{\prime}, 7,7^{\prime}, 8,8^{\prime}$ octahydro-[1, $\left.1^{\prime}\right]$ binaphthyldiimine chiral salen type-ligands for copper-catalyzed asymmetric aziridination. Chirality 2002, 14, 412-416. [CrossRef]

91. Shi, M.; Wang, C.J.; Chan, A.S.C. Axially dissymmetric binaphthyldiimine chiral salen-type ligands for copper-catalyzed asymmetric aziridination. Tetrahedron Assymetry 2001, 12, 3105-3111. [CrossRef]

92. Suga, H.; Kakehi, A.; Ito, S.; Ibata, T.; Fudo, T.; Watanebe, Y.; Kinoshita, Y. Asymmetric Cyclopropanation and Aziridination Reactions of Olefins Catalyzed by Cu(I)-Binaphthyldiimine Complexes. Bull. Soc. Chem. Jpn. 2003, 76, 189-199. [CrossRef]

93. Gillespie, K.M.; Sanders, C.J.; O'Shaughnessy, P.; Westmoreland, I.; Thickitt, C.P.; Scott, P. Enantioselective Aziridination Using Copper Complexes of Biaryl Schiff Bases. J. Org. Chem. 2002, 67, 3450-3458. [CrossRef] [PubMed]

94. Gillespie, K.M.; Crust, E.J.; Deeth, R.J.; Scott, P. Mechanism of alkene aziridination in the [(biaryldiimine)CuI] catalyst system; precise substrate orientation via two-centre binding. Chem. Commun. 2001, 8, 785-786. [CrossRef] 
95. Wang, X.; Ding, K. One-Pot Enantioselective Aziridination of Olefins Catalyzed by a Copper(I) Complex of a Novel Diimine Ligand by Using PhI(OAc)2 and Sulfonamide as Nitrene Precursors. Chem. Eur. J. 2006, 12, 4568-4575. [CrossRef]

96. Xu, J.; Ma, L.; Jiao, P. Asymmetric aziridination of chalcones catalyzed by a novel backbone 1,8-bisoxazolinylanthracene (AnBOX)-copper complex. Chem. Commun. 2004, 1616-1617. [CrossRef]

97. Ma, L.; Jiao, P.; Zhang, Q.; Xu, J. Rigid backbone 1,8-anthracene-linked bis-oxazolines (AnBOXes): Design, synthesis, application and characteristics in catalytic asymmetric aziridination. Tetrahedron Assymetry 2005, 16, 3718-3734. [CrossRef]

98. Ma, L.; Du, D.M.; Xu, J. Rational Tuning Chelate Size of Bis-Oxazoline Ligands to Improve Enantioselectivity in the Asymmetric Aziridination of Chalcones. J. Org. Chem. 2005, 70, 10155-10158. [CrossRef]

99. Ma, L.; Jiao, P.; Zhang, Q.; Du, D.-M.; Xu, J. Ligand and substrate $\pi$-stacking interaction controlled enantioselectivity in the asymmetric aziridination. Tetrahedron Assymetry 2007, 18, 878-884. [CrossRef]

100. Li, Y.; He, J.; Khankhoje, V.; Herdtweck, E.; Köhler, K.; Storcheva, O.; Cokoja, M.; Kühn, F.E. Copper(ii) complexes incorporating poly/perfluorinated alkoxyaluminate-type weakly coordinating anions: Syntheses, characterization and catalytic application in stereoselective olefin aziridination. Dalton Trans. 2011, 40, 5746-5754. [CrossRef]

101. Kantam, M.L.; Jaya, V.S.; Lakshmi, M.J.; Reddy, B.R.; Choudary, B.M.; Bhargava, S.K. Alumina supported copper nanoparticles for aziridination and cyclopropanation reactions. Catal. Commun. 2007, 8, 1963-1968. [CrossRef]

102. Khodadadi, M.R.; Pourceau, G.; Becuve, M.; Wadouachi, A.; Toumieux, S. First Sustainable Aziridination of Olefins Using Recyclable Copper-Immobilized Magnetic Nanoparticles. Synlett 2019, 30, 563-566. [CrossRef]

103. Li, Z.; Ding, X.; He, C. Nitrene Transfer Reactions Catalyzed by Gold Complexes. J. Org. Chem. 2006, 71, 5876-5880. [CrossRef]

104. Yang, K.-S.; Chen, K. A Facile and Highly Diastereoselective Aziridination of Chiral Camphor N-Enoylpyrazolidinones with N-Aminophthalimide. J. Org. Chem. 2001, 66, 1676-1679. [CrossRef]

105. Duan, P.V.; Chiu, C.-C.; Lee, W.-D.; Pan, L.S.; Venkatesham, U.; Tzeng, Z.-H.; Chen, K. On the scope of diastereoselective aziridination of various chiral auxiliaries derived $\mathrm{N}$ - and $\mathrm{O}$-enones with $\mathrm{N}$-aminophthalimide in the presence of lead tetraacetate. Tetrahedron Assymetry 2008, 19, 682-690. [CrossRef]

106. Yang, K.-S.; Chen, K. Enantioselective Aziridination of Alkenes with N-Aminophthalimide in the Presence of Lead TetraacetateMediated Chiral Ligand. Org. Lett. 2002, 4, 1107-1109. [CrossRef] [PubMed]

107. Beletskii, E.V.; Kuznetsov, M.A. Synthesis of oxazoles from $\alpha, \beta$-unsaturated carbonyl compounds through 2-acylaziridines. Russian J. Org. Chem. 2009, 45, 1229-1240. [CrossRef]

108. Pankova, A.S.; Stukalov, A.Y.; Kuznetsov, M.A. Synthesis of 2-(Hetero)aryl-5-(trimethylsilylethynyl)oxazoles from (Hetero)arylacrylic Acids. Org. Lett. 2015, 17, 1826-1829. [CrossRef]

109. Pankova, A.S.; Kuznetsov, M.A. Synthesis and thermal transformations of spiro-fused N-phthalimidoaziridines. Tetrahedron Lett. 2014, 55, 2499-2503. [CrossRef]

110. Kuznetsov, M.A.; Pankova, A.S.; Voronin, V.V.; Vlasenko, N.A. Intramolecular thermal transformations of N-phthalimidoaziridines: 1,3-dipolar cyclo-addition and rearrangements. Chem. Heterocycl. Compd. 2012, 47, 1353-1369. [CrossRef]

111. Li, J.; Liand, J.-L.; Chan, P.V.H.; Che, C.-M. Aziridination of alkenes with N-substituted hydrazines mediated by iodobenzene diacetate. Tetrahedron Lett. 2004, 45, 2685-2688. [CrossRef]

112. Li, J.; Chan, P.V.H.; Che, C.M. Aryl Iodide Mediated Aziridination of Alkenes. Org. Lett. 2005, 7, 5801-5804. [CrossRef] [PubMed]

113. Krasnova, L.B.; Yudin, A.K. Highly Regioselective Transformation of Alkenyl Bromides into $\alpha$-Bromoaziridines and $\alpha$ Bromohydrazones. Org. Lett. 2006, 8, 2011-2014. [CrossRef]

114. Du, X.; Yang, S.; Yang, Y.; Liu, Y. Regio- and Stereoselective Construction of Highly Functionalized 3-Benzazepine Skeletons through Ring-Opening Cycloamination Reactions Catalyzed by Gold. Chem. Eur. J. 2011, 17, 4981-4985. [CrossRef] [PubMed]

115. Schweitzer-Chaput, B.; Keita, M.; Milcent, T.; Ongeri, S.; Crousse, B. Synthesis of fluorinated N-aminoaziridines: Access to new CF3-peptidomimetics. Tetrahedron 2012, 68, 7028-7034. [CrossRef]

116. Yu, S.; Li, X. Mild Synthesis of Chalcones via Rhodium(III)-Catalyzed C-C Coupling of Arenes and Cyclopropenones. Org. Lett. 2014, 16, 1220-1223. [CrossRef] [PubMed]

117. Bakthavachalam, A.; Chuand, H.-C.; Yan, T.-H. Sodium-iodoxybenzoate mediated highly chemoselective aziridination of olefins. Tetrahedron 2014, 70, 5884-5894. [CrossRef]

118. Ulukanli, S.; Karabuga, S.; Celik, A.; Kazaz, C. Substrate-controlled diastereoselective aziridination of alkenes using 3-acetoxyaminoquinazolinone in the presence of hexamethyldisilazane. Tetrahedron Lett. 2005, 46, 197-199. [CrossRef]

119. Atkinson, R.S.; Draycott, R.D.; Hirst, D.J.; Parratt, M.J.; Raynham, T.M. Completely diastereoselective aziridination of $\alpha, \beta-$ unsaturated acids via intramolecular reaction of 3-acetoxyaminoquinazolin-4(3H)-ones. Tetrahedron Lett. 2002, 43, $2083-2085$. [CrossRef]

120. Zibinsky, M.; Butkevich, A.N.; Kuznetsov, M.A. N-Amino-endo-bicyclo[2.2.1]hept-5-ene-2,3-dicarboximide in reaction of oxidative aminoaziridination. Tetrahedron Lett. 2008, 49, 5505-5507. [CrossRef]

121. Samimi, H.A.; Momeni, A.R.J. Aminopyridinium iodide as a NH transferring agent for the synthesis of 2-aroyl-3-aryl aziridines. Iran. Chem. Soc. 2015, 12, 2221-2225. [CrossRef]

122. Sharma, P.; Kumar, A.; Upadhyay, S.; Sahu, V.; Singh, J. Synthesis and QSAR modeling of 2-acetyl-2-ethoxycarbonyl-1-[4(4'arylazo)-phenyl]-N,N-dimethylaminophenyl aziridines as potential antibacterial agents. Eur. J. Med. Chem. 2009, 44, 251-259. [CrossRef] 
123. Siu, T.; Yudin, K. Practical Olefin Aziridination with a Broad Substrate Scope. J. Am. Chem. Soc. 2002, 124, 530-531. [CrossRef] [PubMed]

124. Ghosh, A.; Chavla, V.; Banerjee, P. An Assessment of Electrophilic N-Transfer of Oxaziridine with Different 2-, 3-, and 4-Carbon Donor-Acceptor Substrates to Furnish Diverse N-Containing Heterocycles in a Single Step. Eur. J. Org. Chem. 2019, 23, $3806-3814$. [CrossRef]

125. Nadir, U.K.; Singh, A. Synthesis of Functionalized N-Arylsulfonyl Aziridines from $\alpha, \beta$-Unsaturated Esters, Amides, Ketones, and Nitriles Using N,N-Dichloroarylsulfonamides as Nitrogen Source. Synth. Commun. 2004, 34, 1337-1347. [CrossRef]

126. Chen, D.; Timmons, C.; Guo, L.; Xu, X.; Li, G. One-Pot Stereoselective Synthesis of anti 3-Alkyl and 3-Aryl-N-p-tosyl-aziridine-2ketones and 3-Aryl-N-p-tosyl-aziridine-2-carboxylates. Synthesis 2004, 15, 2479-2484. [CrossRef]

127. Saikia, I.; Kasyap, B.; Phukan, P. A facile noncatalytic pathway for the nitrene transfer process: Expeditious access to aziridines. Chem. Commun. 2011, 47, 2967-2969. [CrossRef] [PubMed]

128. Cai, Y.; Zhou, P.; Liu, X.; Zhao, J.; Lin, L.; Feng, X. Diastereoselectively Switchable Asymmetric Haloaminocyclization for the Synthesis of Cyclic Sulfamates. Chem. Eur. J. 2015, 21, 6386-6389. [CrossRef]

129. Yoshimura, T.; Fujie, T.; Fujii, T. Moderate generation of sulfenylnitrenes from novel N-sulfenylsulfodiimides. Tetrahedron Lett. 2007, 48, 427-430. [CrossRef]

130. Chanda, B.M.; Vyas, R.; Bedekar, A.V. Investigations in the Transition Metal Catalyzed Aziridination of Olefins, Amination, and Other Insertion Reactions with Bromamine-T as the Source of Nitrene. J. Org. Chem. 2001, 66, 30-34. [CrossRef] [PubMed]

131. Sugihara, H.; Daikai, K.; Jin, X.L.; Furuno, H.; Inanaga, J. Catalytic conversion of conjugated enones into optically active $\alpha$-keto aziridines using chiral rare earth metal complexes. Tetrahedron 2002, 43, 2735-2739. [CrossRef]

132. Gasperi, T.; Loreto, M.A.; Tardella, P.A.; Gambacorta, A. Amination of $\alpha$, $\beta$-unsaturated (2-trimethylsilanylmethyl) carboxylic esters. Tetrahedron Lett. 2002, 43, 3017-3020. [CrossRef]

133. Gasperi, T.; Loreto, M.A.; Tardella, P.A.; Veri, E. Synthesis of $\alpha$-amino $\gamma$-butyrolactone derivatives by aziridination of $\alpha$-ylidene $\gamma$-butyrolactones. Tetrahedron Lett. 2003, 44, 4953-4956. [CrossRef]

134. Pesciaioli, F.; De Vincentiis, F.; Galzerano, P.; Bencivenni, G.; Bartoli, G.; Mazzanti, A.; Melchiore, P. Organocatalytic asymmetric aziridination of enones. Angew. Chem. Int. Ed. 2008, 57, 8703-8706. [CrossRef] [PubMed]

135. Arai, H.; Sugaya, N.; Sasaki, N.; Makino, K.; Lectard, S.; Hamada, Y. Enantioselective aziridination reaction of $\alpha, \beta$-unsaturated aldehydes using an organocatalyst and tert-butyl N-arenesulfonyloxycarbamates. Tetrahedron Lett. 2009, 50, 3329-3332. [CrossRef]

136. Nemoto, T.; Hayashi, M.; Xu, D.; Hamajima, A.; Hamada, Y. Enantioselective synthesis of (R)-Sumanirole using organocatalytic asymmetric aziridination of an $\alpha, \beta$-unsaturated aldehyde. Tetrahedron Assymetry 2014, 25, 1133-1137. [CrossRef]

137. Liu, Y.Y.; Duan, S.-W.; Zhang, R.; Liu, Y.-H.; Chen, J.-R.; Xiao, W.-J. Base-catalyzed controllable reaction of 3-ylideneoxindoles with O-Boc hydroxycarbamates for the synthesis of amidoacrylates and spiroaziridine oxindoles. Org. Biomol. Chem. 2016, 14, 5224-5228. [CrossRef]

138. Sabir, S.; Pandey, C.B.; Yadav, A.K.; Tiwari, B.; Jat, J.L. Direct N-H/N-Me Aziridination of Unactivated Olefins Using O(Sulfonyl)hydroxylamines as Aminating Agents. J. Org. Chem. 2018, 83, 12255-12260. [CrossRef]

139. Armstrong, A.; Baxter, C.; Lamont, S.G.; Pape, A.R.; Wincewicz, R. Amine-Promoted, Organocatalytic Aziridination of Enones. Org. Lett. 2007, 9, 351-353. [CrossRef] [PubMed]

140. Armstrong, A.; Pullin, R.D.C.; Jenner, C.R.; Foo, K.; White, A.J.P.; Scutt, J.N. Tertiary amine-promoted enone aziridination: Investigations into factors influencing enantioselective induction. Tetrahedron Assymetry 2014, 25, 74-86. [CrossRef]

141. Armstrong, A.; Pullin, R.D.C.; Scutt, J.N. Tertiary Amine Promoted Aziridination: Preparation of NH-Aziridines from Aliphatic $\alpha, \beta$-Unsaturated Ketones. Synlett 2016, 27, 151-155. [CrossRef] 